\title{
Towards improved instrumentation for assessing river-groundwater interactions in a restored river corridor
}

\author{
P. Schneider ${ }^{1, *}$, T. Vogt ${ }^{1}$, M. Schirmer ${ }^{1}$, J. Doetsch ${ }^{2}$, N. Linde ${ }^{3}$, N. Pasquale ${ }^{4}$, P. Perona ${ }^{4, * *}$, and O. A. Cirpka ${ }^{5}$ \\ ${ }^{1}$ Eawag - Swiss Federal Institute of Aquatic Science and Technology, Überlandstr. 133, 8600 Dübendorf, Switzerland \\ ${ }^{2}$ Institute of Geophysics, ETH Zürich, Sonneggstr. 5, 8092 Zürich, Switzerland \\ ${ }^{3}$ Institute of Geophysics, University of Lausanne, Amphipole Unil Sorge, 1015 Lausanne, Switzerland \\ ${ }^{4}$ Institute for Environmental Engineering, ETH Zürich, Wolfgang-Pauli-Str. 15, 8093 Zürich, Switzerland \\ ${ }^{5}$ Center for Applied Geoscience, University of Tübingen, Sigwartstr. 10, 72076 Tübingen, Germany \\ *now at: Department of Geography, University of Zürich, Winterthurerstr. 190, 8057 Zürich, Switzerland \\ *** now at: AHEAD, IIE, EPFL-ENAC, Station 2, 1015 Lausanne, Switzerland
}

Received: 31 January 2011 - Published in Hydrol. Earth Syst. Sci. Discuss.: 8 March 2011

Revised: 2 July 2011 - Accepted: 15 July 2011 - Published: 16 August 2011

\begin{abstract}
River restoration projects have been launched over the last two decades to improve the ecological status and water quality of regulated rivers. As most restored rivers are not monitored at all, it is difficult to predict consequences of restoration projects or analyze why restorations fail or are successful. It is thus necessary to implement efficient field assessment strategies, for example by employing sensor networks that continuously measure physical parameters at high spatial and temporal resolution. This paper focuses on the design and implementation of an instrumentation strategy for monitoring changes in bank filtration, hydrological connectivity, groundwater travel time and quality due to river restoration. We specifically designed and instrumented a network of monitoring wells at the Thur River (NE Switzerland), which is partly restored and has been mainly channelized for more than 100 years. Our results show that bank filtration - especially in a restored section with alternating riverbed morphology - is variable in time and space. Consequently, our monitoring network has been adapted in response to that variability. Although not available at our test site, we consider long-term measurements - ideally initiated before and continued after restoration - as a fundamental step towards predicting consequences of river restoration for groundwater quality. As a result, process-based models could be adapted and evaluated using these types of highresolution data sets.
\end{abstract}

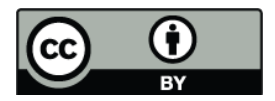

Correspondence to: P. Schneider (philipp.schneider@geo.uzh.ch)

\section{Introduction}

In Switzerland, $40 \%$ of drinking water is pumped from alluvial aquifers, which cover only $5 \%$ of the country's land surface (SVGW, 2004). Mainly for sustaining high pumping rates, many larger drinking water wells are located close to rivers. Open water bodies may be polluted by pathogens or dissolved contaminants, which are introduced into running waters by the effluent of sewage treatment plants, stormwater overflow, and agricultural drainage, among others. The passage through the riverbed, the hyporheic zone, and the alluvial aquifer - summarized as bank filtration - acts as filter and reactor for contaminants, nutrients, and pathogens (Bosma et al., 1996; Bourg and Bertin, 1993; Merkli, 1975; Schwarzenbach et al., 1983, 2006; Schwarzenbach and Westall, 1981). The actual biogeochemical interactions sustaining the quality of the pumped bank filtrate depend on numerous factors including aquifer mineralogy and structure, oxygen and nitrate concentrations in the surface water, types of organic matter in the surface and groundwater environments, and land use in the local catchment area (Hiscock and Grischek, 2002). In rivers with continuous infiltration, the biologically most active zone is typically only a few centimeters thick (von Gunten et al., 1994). Microbial turnover processes are controlled by water temperature, redox potential, dissolved oxygen and available dissolved organic carbon ( $\mathrm{Ja}-$ cobs et al., 1988; von Gunten and Zobrist, 1993). River water differs fundamentally from groundwater with respect to these parameters. Consequently, mixing processes between comparably old groundwater, and fresh river-water infiltrate,

Published by Copernicus Publications on behalf of the European Geosciences Union. 
together with travel times along flowpaths, play a central role for the protection of wells affected by bank filtration (Eckert et al., 2008; Shankar et al., 2009; Tufenkji et al., 2002).

Orghidan (1959) was the first to study the interstitial space below the riverbed as a habitat for aquatic organisms. The hyporheic zone is defined as the transition zone linking river water and groundwater. It is located in the uppermost sediment layers of the riverbed, which - under pristine conditions of alpine rivers - is typically highly permeable for water, organisms, and solutes. Physical, geochemical, or biological evidence of the mixing of the two systems is used to characterize the hyporheic zone (Triska et al., 1989; Woessner, 2000). This mixing is strongly influenced by the heterogeneity of sediments and head gradients (Stauffer and Dracos, 1986; Stanford and Ward, 1993). From an aquaticecology perspective, the hyporheic zone acts as (i) habitat and (ii) modulator for fluctuations in the river, such as those of water temperature, nutrients, and contaminants (Bourg and Bertin, 1993; Brunke and Gonser, 1997; Triska et al., 1993a,b). Our process knowledge about the hyporheic zone remains limited despite its crucial role in reproduction of aquatic organisms, exchange of water and solutes, and transformation of nutrients and contaminants.

Precise knowledge of water levels and their fluctuations are fundamental for interpreting river-groundwater interactions or for applying and calibrating groundwater models. Attempts to simulate local effects of river-aquifer exchange in river-scale models are usually hampered by the lack of field data on riverbed conductivities and hydraulic gradients within the riverbed, which are seldom available at the appropriate scale and temporal resolution. Regional groundwater monitoring networks usually do not have sufficient spatial density in the vicinity of the river to reliably calibrate local riverbed conductivities. Therefore, local conditions at the interface between the river and the aquifer may not be adequately represented in a model (Fleckenstein et al., 2006).

Exchange fluxes between rivers and groundwater are highly variable in time and space (Brunke and Gonser, 1997; Wroblicky et al., 1998). Temporal fluctuations can be attributed to changing hydrological conditions (Vogt et al., 2010b; Wroblicky et al., 1998) as well as clogging and declogging of the riverbed (Battin and Sengschmitt, 1999; Schälchli, 1992). The heterogeneity of streambed sediments and associated hydraulic conductivity (Fleckenstein et al., 2006; Huggenberger et al., 1996; Kalbus et al., 2009), riverbed morphology and stream curvature (Cardenas et al., 2004; Gooseff et al., 2005; Harvey and Bencala, 1993), and spatially varying hydraulic gradients (Storey et al., 2003) may cause spatial variations. All the above-mentioned factors controlling river-groundwater interactions may be affected by river restoration measures.

The central goal of the EU water framework directive (European Commission, 2000) is to achieve a "good ecological status" of all water bodies. This requires intensive vertical hyporheic exchange, lateral connection with floodplains and alluvial forests and longitudinal connectivity for aquatic fauna of running water systems (Stanford and Ward, 1988, 1993; Ward, 1989). Consequently, Swiss law requires river restoration in all flood-protection measures (GSchG, 1991; GSchV, 1998). Typical components of river restoration include the widening of the river course, the removal of bank stabilization, and the reestablishment of a more natural sediment regime. In contrast to ecological benefits, enhanced hydrological connectivity and fast infiltration may cause problems, such as breakthrough of contaminants in drinking water wells located close to rivers. This made Swiss legislators prohibit river restoration measures within protection zones of drinking water wells (BUWAL, 2004; SVGW, 2007). This legislation reflects the concern that river restoration might impair groundwater quality. It also shows that interactions of groundwater and river water at restored sites, and their effects on water supply, are not yet fully understood.

Each restoration project is potentially an opportunity to learn more about aquatic systems and how they are modified following restoration (Kondolf, 1998; Regli et al., 2003). Adequate process knowledge is fundamental to understanding the impact of river restoration on groundwater systems. Such a mechanistic system understanding can only be derived by site-specific monitoring, optimally performed prior to and post restoration. Restoration should ideally be based on process understanding instead of mimicry of form (morphology). This has consequences on evaluating restoration success as current practice is restricted to mainly monitoring the morphodynamics of the restored river section, and perhaps performing a few surveys on the abundance of indicator organisms (Woolsey et al., 2007). This type of program needs to be extended to include measures of system functioning with respect to hyporheic exchange, biogeochemistry and water quality. Such post-restoration performance evaluation is needed to avoid repeating mistakes, to develop an understanding of how rivers respond to restoration actions, and to allow for improved river restoration schemes in the future.

A variety of techniques has been developed to estimate water exchange rates between rivers and aquifers (Kalbus et al., 2006), but a comprehensive analysis of river-groundwater exchange and its effects on water quality requires more than estimates of water fluxes in the riverbed at individual locations and single points in time. Continuous monitoring of variables related to river-groundwater exchange is needed to understand dynamic behavior. These monitoring data can be analyzed by numerical models, which require geometric and structural information about the river and the aquifer. This paper deals with preliminary surveys, as well as instrumentation and monitoring strategies adapted for better hydrological understanding of restored river corridors. In particular, we focus on the following components:

- Surveys targeting topography and bathymetry, which record morphological changes that can be used to create a hydraulic model of the river. 
- Surveys targeting the subsurface structure, which are mainly performed by geophysical techniques; this structural information about the subsurface is necessary to characterize heterogeneity of aquifer deposits and to create reliable groundwater flow and transport models.

- Surveys targeting water levels, which consist of continuous level gauging both in the river and in monitoring wells, but also automated visual monitoring of the river with subsequent image analysis.

- Surveys targeting solute transport and water quality by continuous sensing of physical parameters (temperature and electrical conductivity) in the river and in the groundwater with subsequent time-series analysis, and by regular sampling campaigns for chemical parameters.

Instrumentation within the riverbed is desired but challenging, as equipment and monitoring networks are prone to flooding, erosion, sedimentation and other physical stresses, leading to sensor failure and complete loss of data sets. We present an approach to tackle this problem by tailoring a monitoring-well network outside of the riverbed with focus on bank filtration, groundwater travel times, hydrologic connectivity and related changes in water quality. We demonstrate the applicability of this process-driven approach and show how targeted monitoring enables us to understand inand exfiltration in space and time at a restored section of the Thur River in Switzerland, which forms our case-study.

The Thur River is currently under intensive investigation with respect to exchange processes between river and aquifer within the project "Assessment and Modeling of Coupled Ecological and Hydrological Dynamics in the Restored Corridor of a River - Restored Corridor Dynamics (RECORD)" (http://www.cces.ethz.ch/projects/ nature/Record, 2010). While the RECORD project also has an ecological component, this paper focuses on physical processes and water quality only. The purpose of the current contribution is to give an overview of the various methods applied at the River Thur. Details of individual techniques have already been published by Coscia et al. (2011), Diem et al. (2010), Doetsch et al. (2010a,b; 2011), Schäppi et al. (2010), and Vogt et al. (2009; 2010a,b). The special issue, in which this paper appears, contains additional descriptions about individual aspects (Edmaier et al., 2011; Hoehn and Scholtis, 2011; Linde et al., 2011; Pasquale et al., 2011; Samaritani et al., 2011). In this paper, we put these individual contributions into a common context.

\section{Thur catchment and test site selection}

The Thur Valley aquifer is one of the largest groundwater systems in Switzerland with a length of $36 \mathrm{~km}$, a width of $2 \mathrm{~km}$ and a depth of up to $20 \mathrm{~m}$ and it is mainly fed by the

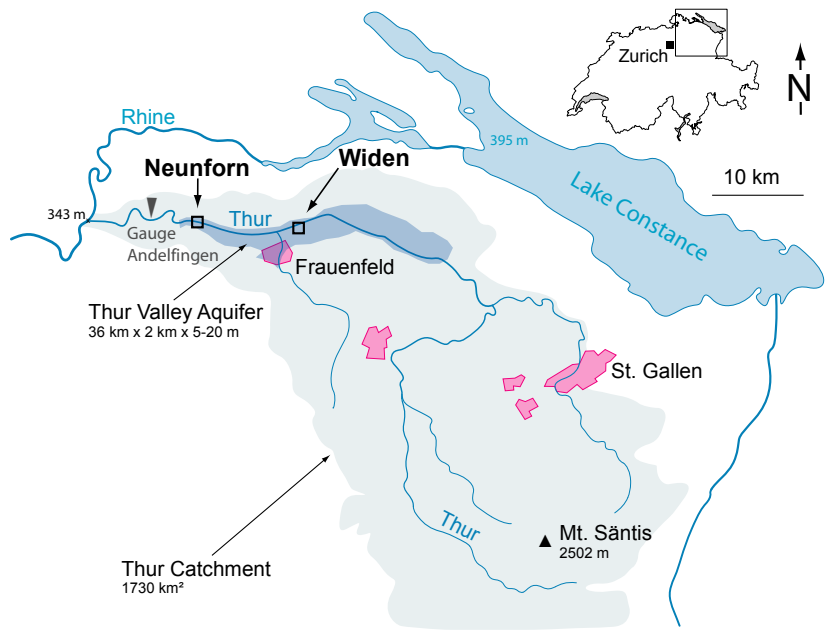

Fig. 1. Location of the Thur catchment, the Thur valley aquifer and the test sites at Neunforn (partly restored) and Widen (channelized) in NE Switzerland.

Thur River. As the aquifer is widely used for drinking water abstraction, changes in travel times from river to nearby pumping stations caused by river restoration are a critical issue, especially since this aquifer, like others in alpine environments, exhibits high hydraulic conductivities.

The Thur catchment is located in north-eastern Switzerland, draining the front ranges of the Swiss Limestone Alps (Alpstein) south of Lake Constance into the River Rhine (Fig. 1). It is a primarily rural catchment, with agricultural activity mainly in the lowlands, and a few towns and villages (Table 1). Water quality in the Thur catchment is adversely influenced by intensive agriculture and sewage water inflows (Table 1) mainly in the lower part of the catchment. The geology is formed by mainly limestone dominated alpine headwaters with high annual rainfall (Mt. Säntis $\approx 2500 \mathrm{~mm} \mathrm{yr}^{-1}$; Seiz and Foppa, 2007), whereas the lowlands are dominated by Molasse sandstones and Pleistocene unconsolidated sediments. The Thur Valley and its aquifer are dominated by glacio-fluvial sandy gravels overlaying lacustrine clays (Table 2). The gravel deposition occurred within a few thousand years at the end of the last ice age during the retreat of the last Rhine glacier. In some parts of the valley, natural alluvial fines of up to $3 \mathrm{~m}$ thickness act as a confining layer. In the lower Thur Valley, the river cuts into sandy gravel sediments. Towards the western end of the valley, the gravel sediments form a single layered, 5-7 m thick aquifer with an average hydraulic conductivity of $5 \times 10^{-3} \mathrm{~m} \mathrm{~s}^{-1}$ derived by pumping tests (variance: $\sigma_{\text {logk }}^{2}=0.4$; Baumann et al., 2009). The lacustrine silty clay below the gravel can be considered to be impervious.

Regional groundwater flow is dominated by infiltration of the Thur River at the eastern (upstream) end of the valley $\left(\approx 0.26 \mathrm{~m}^{3} \mathrm{~s}^{-1}\right)$, groundwater recharge over the entire area of the valley $\left(\approx 0.49 \mathrm{~m}^{3} \mathrm{~s}^{-1}\right)$, groundwater extraction 


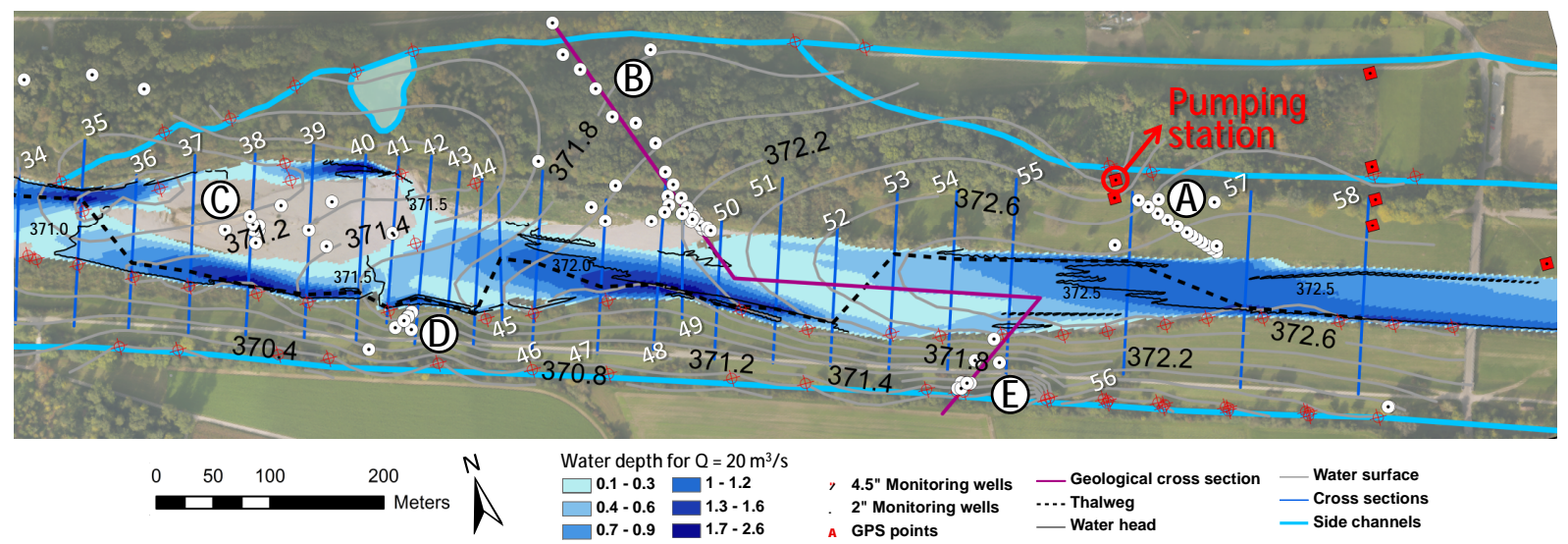

Fig. 2. Test site Neunforn, partly restored (left) and partly channelized (right) with monitoring-well transects A, B, C, D, E (Table 3). Thalweg (dashed black line), surface water levels (solid black line) and water depths (blue color coded) for River Thur under low-flow conditions $\left(20 \mathrm{~m}^{3} \mathrm{~s}^{-1}\right)$. Contourlines of groundwater heads (light grey solid lines) are based on interpolated surface-water levels in the river (measured at flows of approximately $30 \mathrm{~m}^{3} \mathrm{~s}^{-1}$ ) and the side channels with a differential GPS (red crosses). Bathymetric surveys are conducted annually in September by measuring predefined cross-sections blue lines with white numbering).

by pumping wells $\left(\approx 0.36 \mathrm{~m}^{3} \mathrm{~s}^{-1}\right)$, and exfiltration into side channels at the western (downstream) end of the valley. This behavior is strongly modified in the vicinity of the river by river-water infiltration $\left(\approx 3.0 \mathrm{~m}^{3} \mathrm{~s}^{-1}\right)$, short passages through the aquifer and exfiltration into the side channels in the western part of the valley. The water balance of a regional groundwater model (Table 2) revealed that about $86 \%$ of the total water collected by the side channels $\left(\approx 3.1 \mathrm{~m}^{3} \mathrm{~s}^{-1}\right)$ is fresh river-water infiltrate (Baumann et al., 2009).

Originally, the lower Thur River was a braided gravel-bed river characterized by a shifting mosaic of channels, ponds, bars and islands occupying most of the valley floor. Like most major rivers in central Europe, the lower Thur River was channelized by the end of the 19th century to gain arable land and avoiding frequent flooding. Thus, the Thur River was converted into a double trapezoidal channel with stabilized banks and bounded by levees (for a detailed description see Pasquale et al., 2011). In 2002, a $2 \mathrm{~km}$ long section of the Thur River near Neunforn/Altikon was restored by completely removing the northern overbank, so that the nearby alluvial forest became part of the active floodplain again. This large widening increased sediment deposition, reestablished dynamic fluvio-morphological processes with frequently forming and alternating gravel bars, and created physical habitats for pioneer fauna and flora. This river section is the focus of this study.

Figures 1 and 2 provide an overview of the selected test site. While the upstream (eastern) reach of the site has remained channelized, the downstream (western) reach has been significantly modified by restoration, giving us the opportunity to compare bank filtration under pre- and postrestoration conditions at a single site. In the downstream reach, where the northern overbanks have been removed, the width of the active river channel has been extended to more than $100 \mathrm{~m}$ (Fig. 3). A municipal abstraction well - referred to as the pumping station in the following - is located in the upstream reach of the test site (see transect A in Fig. 2). The northern levee ends near the pumping station (Fig. 2). Parallel to it runs a side channel draining the northern floodplain. This channel joins the river within the test-site perimeter and exhibits similar water level fluctuations as the river, which implies only moderate hydraulic gradients between them. Consequently, the principle direction of groundwater flow along the northern bank of the Thur River is expected to be almost parallel to the river.

Widening of the river bed in the course of restoration has caused sedimentation of bed load at the site. Schälchli (2008) estimated the gravel deposition in the $2 \mathrm{~km}$ long restored sector at the site to be approximately $8000 \mathrm{~m}^{3}$ per year (Figs. 1, 2 and 3). This estimate highlights that significant changes in morphology are expected in the next years. A particular goal of this study is to assess the effects of these morphological changes on mixing ratios of groundwater and river water, related travel times, and nutrient and pollutant turnover.

\section{Preliminary investigations}

All existing data about the site were taken into account to design a continuously operating monitoring network. Existing reports (identification of well protection zone), maps (hydrogeology, paleochannels, digital terrain models or orthophotos), and data series (hydrological yearbooks of river and groundwater gauges, case studies), formed the initial basis for estimating hydraulic heads, groundwater flow direction, and hydraulic conductivities. In the Thur Valley, cantonal authorities have collected time series of hydraulic head, water temperature and electrical conductivity in the Thur River and 


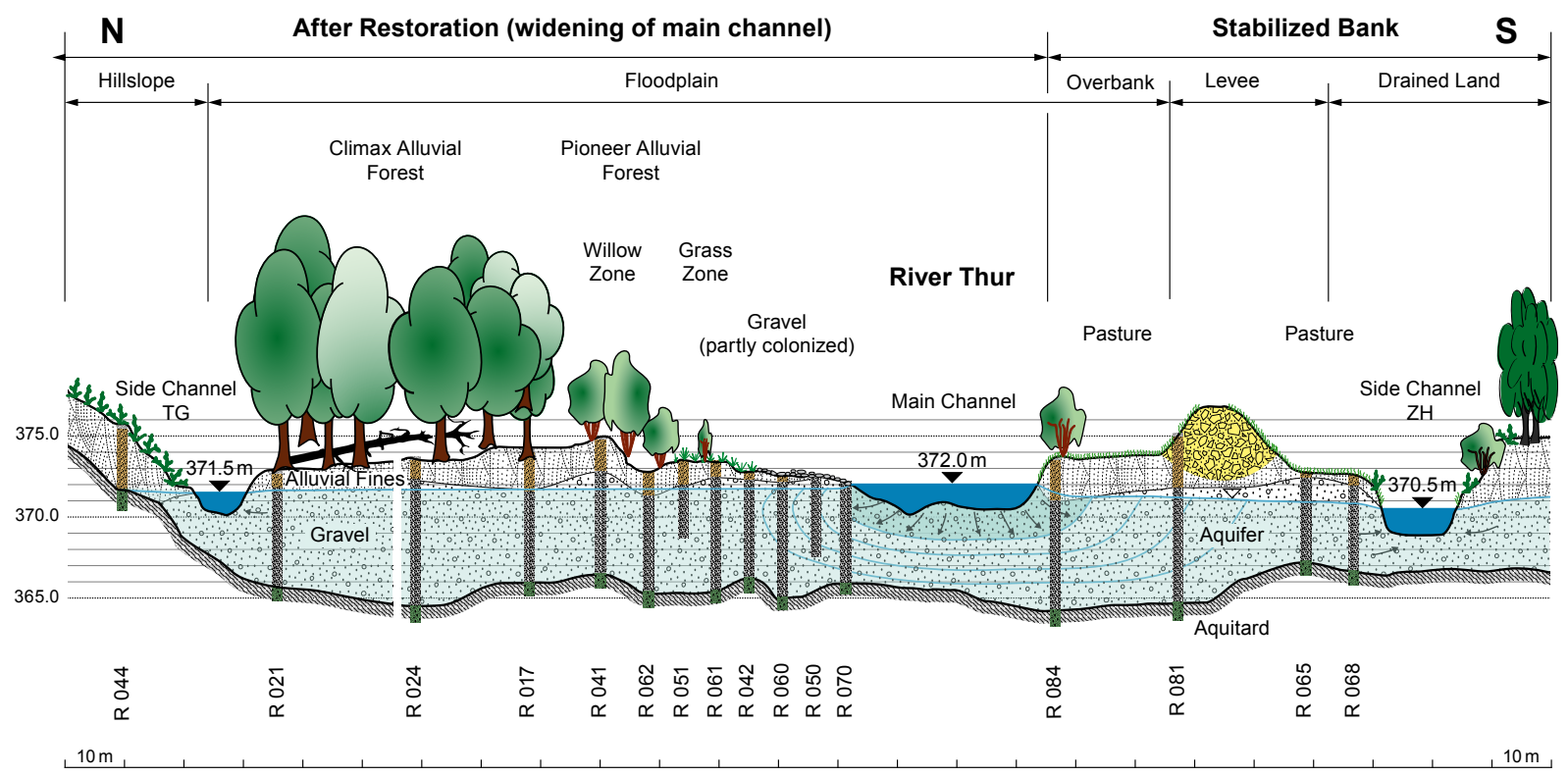

Fig. 3. Geological cross-section representing restored (left; R044 to R070 forming transect B in Fig. 2) and channelized (right; R084 to R068 forming transect E in Fig. 2) transects at the test site Neunforn. The restored parts comprises gravel bars developed naturally after restoration in 2002 - including the gravel zone, sparsely colonized with pioneer plants, and the grass zone characterized by thick layers of young alluvial overbank sediments densely colonized with mainly reed grass (Phalaris arundinacea) - the willow zone where older alluvial sediments were stabilized during restoration by planting young Salix viminalis, and the alluvial forest dominated by ash and maple growing on older alluvial sediments.

at a small number of adjacent monitoring wells over the last ten years.

While Sect. 4 mainly describes the design of the network of instrumented monitoring wells, we discuss in this section surveys performed prior to the installation of these monitoring wells that went beyond standard surveys performed by the cantonal authorities. Some of these surveys were repeated to document dynamic changes.

\subsection{Geodetic surveys, bathymetry, and hydraulic-head measurements}

River restoration significantly modifies river and floodplain morphologies and their dynamic behavior. Installing monitoring wells in the riverbed or close to the river thus requires knowledge of erosion and sedimentation dynamics. For instance, in the restored section of our test site, erosion and deposition processes are quite active because of frequent floods. This results in successive alterations of the fluvial morphology and the local riverbed topography, which in turn creates dynamic boundary conditions for surface and groundwater flow. Consequently, monitoring and modeling of the topography of the riverbed and the floodplain area are fundamental. To achieve this, we developed a comprehensive approach to monitor the morphodynamic evolution of restored river corridors based on airborne laser scan surveys with synchronous bathymetric surveying (Pasquale et al., 2011).
Figure 2 illustrates how the results of a differential-GPS survey can be used to estimate the hydraulic-head distribution within the aquifer. We measured the water level of the river, the side channels and the existing monitoring wells and interpolated these head values by ordinary kriging with a linear variogram, resulting in the light grey contour lines on Fig. 2. The implicit assumptions made by this interpolation are that groundwater flow is strictly horizontal (Dupuit assumption) and that the hydraulic contact between river and groundwater is perfect. Both assumptions must be investigated, but the resulting maps of groundwater levels give a first indication of hydraulic gradients (Table 3, Fig. 2) and groundwater flow directions. Based on these data we could identify losing stream conditions, areas with high hydraulic gradients and locations of potentially significant exfiltration into the side channels.

The river stage is generally higher than in the side channels. The northern side channel is flowing back into the river downstream of the central gravel bar shown in Fig. 2, whereas the confluence of the southern side channel is located $1.5 \mathrm{~km}$ further downstream. This explains the higher gradients towards the southern channel and the dominance of the southern side channel in draining the entire river corridor (Baumann et al., 2009). Similarly, the groundwater level and the direction of hyporheic flows through gravel bars could be initially estimated with simple measurements of the surfacewater level. 
Table 1. Key descriptors of the Thur River (BAFU, 2010).

\begin{tabular}{|c|c|}
\hline Catchment Area & $1730 \mathrm{~km}^{2}$ \\
\hline Catchment Gauge & $1696 \mathrm{~km}^{2}$ \\
\hline Level of Gauge & $356 \mathrm{~m}$ a.s.l. \\
\hline Average Altitude & $770 \mathrm{~m}$ a.s.l. \\
\hline Maximum Altitude & 2502 m a.s.l. \\
\hline Glaciers & $0.0 \%$ \\
\hline Flow Regime & $\begin{array}{l}\text { nivo-pluvial } \\
\text { (snowmelt dominated) }\end{array}$ \\
\hline Annual Rainfall (Thur catchment) & 1413 mm (1961-1990) \\
\hline Annual Rainfall (Thur Valley) & $883 \mathrm{~mm}(1961-1990)$ \\
\hline Mean Runoff (MQ) & $\begin{array}{l}47.0 \mathrm{~m}^{3} \mathrm{~s}^{-1} 0.098 \mathrm{~mm} \mathrm{~h}^{-1} \\
(1904-2008)\end{array}$ \\
\hline Max. Runoff (HHQ) & $\begin{array}{l}1130 \mathrm{~m}^{3} \mathrm{~s}^{-1} 2.35 \mathrm{~mm} \mathrm{~h}^{-1} \\
(1999)\end{array}$ \\
\hline Min. Runoff (NNQ) & $\begin{array}{l}2.24 \mathrm{~m}^{3} \mathrm{~s}^{-1} 0.005 \mathrm{~mm} \mathrm{~h}^{-1} \\
(1947)\end{array}$ \\
\hline $99.7 \%$ exceedance (MNQ, $Q_{365}$ ) & $3.83 \mathrm{~m}^{3} \mathrm{~s}^{-1} 0.008 \mathrm{~mm} \mathrm{~h}^{-1}$ \\
\hline $95 \%$ exceedance $\left(Q_{347}\right)$ & $9.32 \mathrm{~m}^{3} \mathrm{~s}^{-1} 0.019 \mathrm{~mm} \mathrm{~h}^{-1}$ \\
\hline $90 \%$ exceedance $\left(Q_{329}\right)$ & $12.0 \mathrm{~m}^{3} \mathrm{~s}^{-1} 0.025 \mathrm{~mm} \mathrm{~h}^{-1}$ \\
\hline $50 \%$ exceedance $\left(Q_{182}\right)$ & $33.0 \mathrm{~m}^{3} \mathrm{~s}^{-1} 0.069 \mathrm{~mm} \mathrm{~h}^{-1}$ \\
\hline $10 \%$ exceedance $\left(Q_{36}\right)$ & $95.7 \mathrm{~m}^{3} \mathrm{~s}^{-1} 0.199 \mathrm{~mm} \mathrm{~h}^{-1}$ \\
\hline $5 \%$ exceedance $\left(Q_{18}\right)$ & $130 \mathrm{~m}^{3} \mathrm{~s}^{-1} 0.271 \mathrm{~mm} \mathrm{~h}^{-1}$ \\
\hline $0.3 \%$ exceedance $\left(Q_{1}\right)$ & $382 \mathrm{~m}^{3} \mathrm{~s}^{-1} 0.795 \mathrm{~mm} \mathrm{~h}^{-1}$ \\
\hline MHQ & $585 \mathrm{~m}^{3} \mathrm{~s}^{-1} 1.22 \mathrm{~mm} \mathrm{~h}^{-1}$ \\
\hline $\mathrm{HQ}_{10}$ & $818 \mathrm{~m}^{3} \mathrm{~s}^{-1} 1.70 \mathrm{~mm} \mathrm{~h}^{-1}$ \\
\hline HHQ/MQ ratio & $24: 1$ \\
\hline MHQ/MQ ratio & $12: 1$ \\
\hline MNQ/MQ ratio & $1: 12$ \\
\hline River Order (Strahler, 1952) & 7 \\
\hline River Length & $127 \mathrm{~km}$ \\
\hline River Slope (upper, middle, lower part) & $10-20 \%, 3-4 \%, 1.6-2 \%$ \\
\hline Northern Side Channel Slope & $1-1.5 \%$ \\
\hline Southern Side Channel Slope & $1-1.5 \%$ \\
\hline Landuse Agriculture & $\begin{array}{l}61 \% \text { ( } 85 \% \text { grassland, } \\
15 \% \text { intensive agriculture) }\end{array}$ \\
\hline Landuse Forest & $30 \%$ \\
\hline Landuse Residential & $\begin{array}{l}9 \% \text { (66\% settlements, } \\
33 \% \text { streets) }\end{array}$ \\
\hline Livestock Unit Density & $118 \mathrm{LU} \mathrm{km}^{-2}$ \\
\hline Population Density: Inhabitants & $223 \mathrm{In} \mathrm{km}^{-2}$ \\
\hline Sewage Inhabitant Equivalents & $221 \mathrm{InE} \mathrm{km}^{-2}$ \\
\hline Sewage Contribution at low Flows & up to $30 \%$ \\
\hline
\end{tabular}

\subsection{Geophysical surveys}

Surface-based electrical resistivity tomography (ERT) (Günther et al., 2006) was used to obtain 2-D electrical resistivity profiles crossing the river. In saturated porous media, electrical resistivity is primarily related to porosity, pore structure, salinity, and clay content (Lesmes and Friedman, 2005). Electrical resistivity models can thus be used to image the loam-gravel-clay sequences along the unrestored and restored river sections, as well as lateral variations in porosity within the gravel aquifer. In order to obtain reliable resistivity images it is important to incorporate the river water as a known conductive feature (we measured the electrical resistivity of the water when performing the measurements) and to accurately (within a few $\mathrm{cm}$ ) determine the electrode positions.
Table 2. Key descriptors of the Thur Valley aquifer (Baumann et al., 2009).

\begin{tabular}{ll}
\hline Length & $36 \mathrm{~km}$ \\
Width & $2-3 \mathrm{~km}$ \\
Depth & $5-20 \mathrm{~m}$ \\
Altitude & $380 \mathrm{~m}$ a.s.l. \\
Hydraulic Conductivity of the Riverbed & $10^{-3}-10^{-4} \mathrm{~m} \mathrm{~s}^{-1}$ \\
Annual Rainfall & $900 \mathrm{~mm}$ \\
Potential ETP & $600 \mathrm{~mm}^{3}$ \\
Local Recharge & $0.49 \mathrm{~m}^{3} \mathrm{~s}^{-1}$ \\
Lateral Inflows & $0.1 \mathrm{~m}^{3} \mathrm{~s}^{-1}$ \\
Exfiltration & $3.1 \mathrm{~m}^{3} \mathrm{~s}^{-1}$ \\
Infiltration & $3.0 \mathrm{~m}^{3} \mathrm{~s}^{-1}$ \\
Abstraction (via pumping wells) & $0.36 \mathrm{~m}^{3} \mathrm{~s}^{-1}$ \\
\hline
\end{tabular}

Figure 4 displays an electrical resistivity model obtained for a profile that is perpendicular to the river upstream of the restored river section (crossing transect A in Fig. 2). We used 89 electrodes with an electrode spacing of $2 \mathrm{~m}$ and a total of 5743 measurements (a combination of Wenner and dipole-dipole arrays). The resulting model has a data misfit just above $3 \%$. The gravel aquifer is readily identified as an approximately $6 \mathrm{~m}$ thick horizontal layer of moderate resistivities ( $>100 \Omega \mathrm{m}$ ). The underlying less resistive layer corresponds to lacustrine clay and the upper $2-3 \mathrm{~m}$ on each side of the river corresponds to alluvial fines. The model does not indicate any conductive clogging layer at the rivergravel interface. Within the gravel aquifer it is possible to image regions of higher resistivities and thus lower porosities. ERT profiles that cross the river can only be acquired under low-flow conditions and three operators can acquire 2-3 such ERT profiles in a day.

Surface-based ground-penetrating radar (GPR) data provide more detailed information about the internal structure of the gravel aquifer (Beres et al., 1999; Lunt et al., 2004). This technique transmits a high-frequency electromagnetic pulse into the ground and the reflected energy is recorded. Reflections occur at locations where dielectric properties change, which mainly correspond to variations in water content. We have acquired extensive three-dimensional (3-D) GPR and ERT surveys at a gravel bar within the restored section of the Thur River (downstream of transect B in Fig. 2).

Figure 5a displays a GPR reflection profile extracted along the beginning of transect B (Fig. 2). From the GPR data we can identify the gravel-clay boundary as a rather strong reflection, which can be traced throughout the gravel bar, followed by much weaker signals (GPR signals are strongly attenuated in clay formations). The reflectivity patterns display a rather complex sub-horizontal layering within the gravel deposits. The fully processed 3-D GPR volume allowed us to map internal interfaces within the gravel throughout the gravel bar and made it possible to identify different 
Table 3. Comparison of the five monitoring-well transects A, B, C, D and E at the test site Neunforn $(\mathrm{x}=$ done, $\mathrm{xx}=$ intensively done with focus, $-=$ not done at that transect). The locations of the transects are illustrated in Fig. 2.

\begin{tabular}{llllll}
\hline Parameter & A & B & C & D & E \\
\hline Transect Name & Pumping Station & Forest & Central Bar & Levee Downstream & Levee Upstream \\
Number of Wells & 18 & 29 & 12 & 7 & 9 \\
Transect Length & $135 \mathrm{~m}$ & $190 \mathrm{~m}$ & $80 \mathrm{~m}$ & $70 \mathrm{~m}$ & $60 \mathrm{~m}, 85 \mathrm{~m}$ \\
Head Difference & $0.5 \mathrm{~m}$ & $0.25 \mathrm{~m}$ & $0.5 \mathrm{~m}$ & $1.0 \mathrm{~m}$ & $1.5 \mathrm{~m}$ \\
Hydraulic & $3.7 \% 0$ & $1.3 \% 0$ & $6.3 \% 0$ & $14.3 \% 0$ & $25 \%$, \\
Gradient & & & & & $17.6 \% 0$ \\
Slug-Tests & $\mathrm{x}$ & $\mathrm{x}$ & - & - & - \\
Focus Exfiltration & - & - & - & - & $\mathrm{x}$ \\
Focus Infiltration & $\mathrm{x}$ & $\mathrm{x}$ & - & $\mathrm{x}$ & $\mathrm{x}$ \\
Forced Tracer Tests & $\mathrm{x}$ & $\mathrm{x}$ & - & - & - \\
Unforced Tracer Tests & - & $\mathrm{x}$ & - & - & $\mathrm{x}$ \\
Geophysical Survey & $\mathrm{x}$ & $\mathrm{xx}$ & $\mathrm{x}$ & - & - \\
Sampling & $\mathrm{x}$ & $\mathrm{xx}$ & - & $\mathrm{x}$ & - \\
Sensing & $\mathrm{x}$ & $\mathrm{xx}$ & $\mathrm{x}$ & $\mathrm{x}$ & $\mathrm{x}$ \\
Multi Level Sensing & - & $\mathrm{xx}$ & - & $\mathrm{x}$ & $\mathrm{xx}$ \\
Online Sensing & - & $\mathrm{xx}$ & $\mathrm{x}$ & $\mathrm{x}$ & - \\
Lost Sensors & - & - & $\mathrm{x}$ & - & - \\
\hline
\end{tabular}

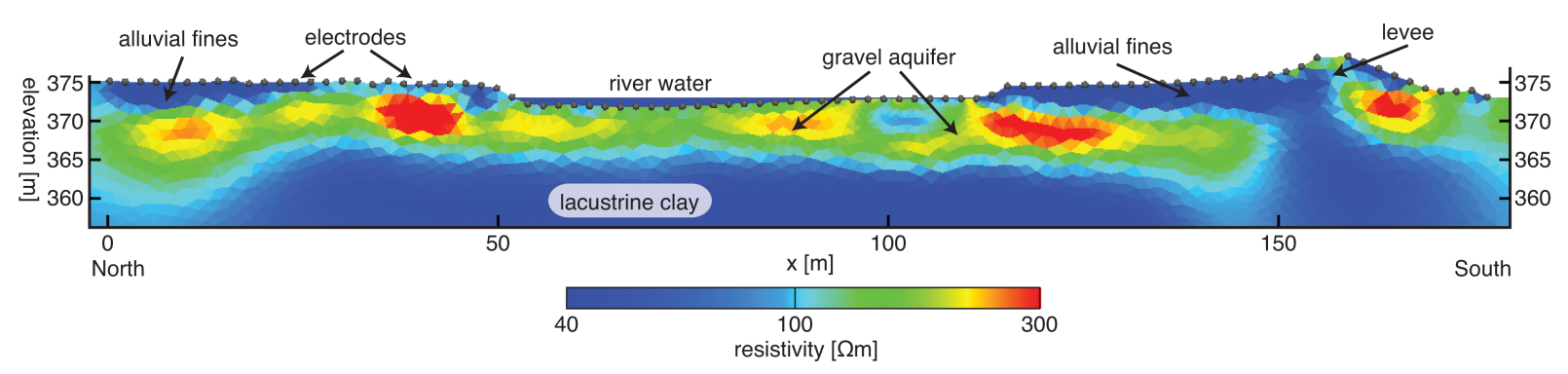

Fig. 4. Electrical resistivity model crossing the Thur River at right angles in the vicinity of the pumping-station transect (transect A in Fig. 2). The moderately resistive gravel deposits (green and red) can be distinguished from the overlying more conductive loamy topsoil (blue) and the underlying lacustrine clays (blue). Low porosity regions within the gravel deposits (red) can also be identified.

sedimentological features, such as an ancient paleochannel (Doetsch et al., 2011).

Figure 5b displays an ERT model along transect B (Fig. 2) using 23 electrodes and a $2 \mathrm{~m}$ spacing with a total of 408 measurements. The data misfit was just above $3 \%$. The electrical resistivity model displays a top layer of alluvial fines, increasing in thickness with distance to the river (this soil layer and abundant vegetation make it impossible to obtain GPR images along the entire transect). To construct the ERT image, we used information about the depth of the gravel-clay interface from Fig. 5a to better image the sharp transition between the underlying clay and the gravel aquifer. This approach has been extended in 3-D at the scale of the whole gravel bar by Doetsch et al. (2011).

\subsection{Streambed conductivity}

Hydraulic conductivity of streambed and alluvial sediments ranges over several orders of magnitude. Therefore, the exchange between rivers and groundwater depends largely on the spatial arrangement of hydrofacies (Fleckenstein et al., 2006; Miall, 1995; Woessner, 2000). In order to investigate the hydraulic conductivity of the riverbed we have performed slug tests using temporary shallow piezometers with $0.1 \mathrm{~m}$ screen length ( $0.01 \mathrm{~m}$ screen holes with inside screen cloth). The experiments were conducted in the restored riverbed of our test site near Neunforn (Figs. 1-3 and Table 3). As it is difficult to permanently install and protect monitoring-wells in the main river channel (e.g. near the thalweg), we also performed slug tests at a reference test site about $15 \mathrm{~km}$ upstream near Widen, which is still channelized (Fig. 1). Our results show that the uppermost $50 \mathrm{~cm}$ of the riverbed have a higher hydraulic conductivity than the deeper sediments (we measured at two test sites a total of 33 locations at depths of $50 \mathrm{~cm}, 100 \mathrm{~cm}, 150$ and $200 \mathrm{~cm}$ ). As hydraulic conductivities at the two sites do not differ significantly, we computed the statistics of the merged data set, obtaining a lognormal 


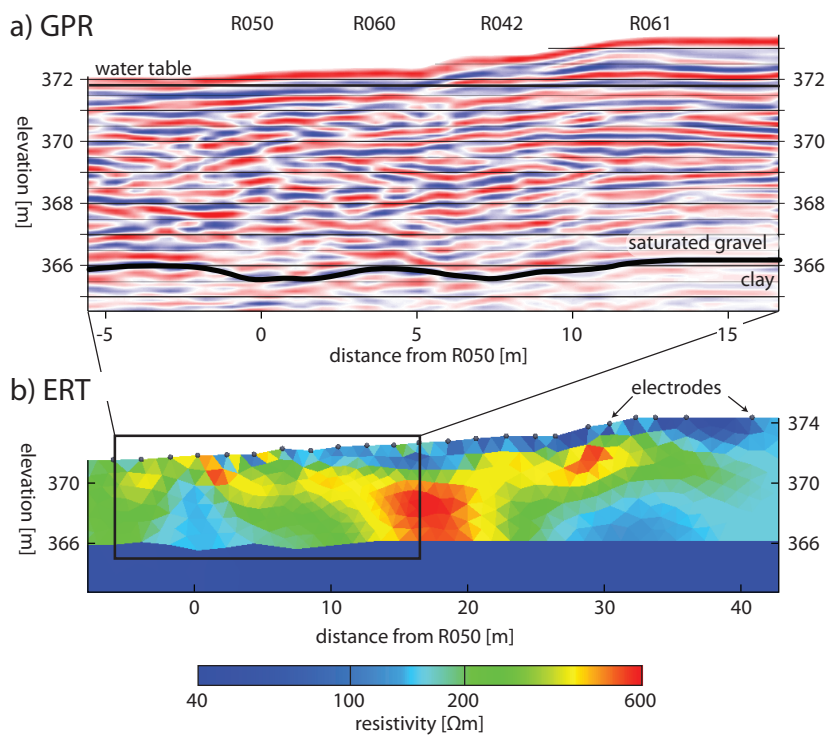

Fig. 5. (a) GPR reflection profile and (b) ERT model obtained in the beginning of the forest transect (transect B in Fig. 2). GPR reflections provide high-resolution information about lithological variations, whereas ERT provides information about average porosities and clay content at a lower resolution.

distribution with a geometric mean of $2 \times 10^{-4} \mathrm{~m} \mathrm{~s}^{-1}$ and a $\log _{10}$ variance of 1.6 . The mean value is considerably smaller than those expected for a gravel aquifer (see results presented in the following) suggesting that the hydraulic contact between the gravel aquifer and the river may be imperfect, at least at the locations where the slug tests were performed. Together with slug tests, hydraulic heads in the temporary piezometers and the river water were measured, facilitating the estimation of infiltration rates, which were in the range of $4-8 \times 10^{-5} \mathrm{~m} \mathrm{~s}^{-1}$.

\subsection{Hydrochemical surveys}

We measured Radon-222 and other environmental tracers (SF6, CFCs, Tritium/Helium, O-18/Deuterium) in six preexisting cantonal monitoring wells on the northern side of the Thur River (near the pumping station, transect A in Fig. 2) to estimate groundwater residence times and mixing ratios (Kipfer et al., 2002). The travel times at our test site are in the range of several days, making Radon-222 the most suitable dissolved-gas tracer for dating. North of the river, fresh infiltrate was only observed between the Thur River and the side channel. At our test site, no monitoring wells existed between the river and the southern side channel prior to the RECORD project, but the large head difference between the Thur River and the southern side channel made us believe that the groundwater in between is dominated by fresh river infiltrate. In general, the groundwater of the investigation area can be described as calcium-bicarbonate water.
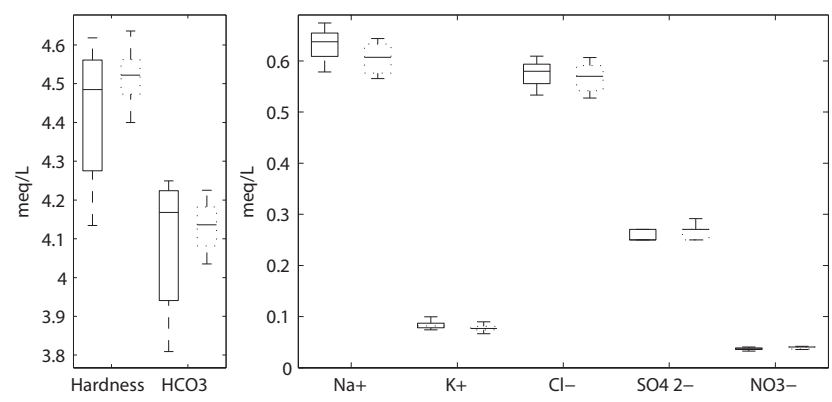

Fig. 6. Box plots comparing daily variation in hydrochemistry in river (solid) and near-river groundwater (dotted) in a monitoringwell R042 in the forest transect (transect B in Fig. 2) sampled every two hours over a period of two successive summer days. The line in the middle of each box is the sample median. If the median is not centered in the box, it shows sample skewness. The tops and bottoms of each "box" are the 25th and 75th percentiles of the samples, respectively. The distances between the tops and bottoms are the inter-quartile ranges. Whiskers are drawn from the ends of the inter-quartile ranges to the furthest observations within the whisker length (the adjacent values).

Groundwater chemistry not only exhibits spatial trends but also temporal variations. Daily, event-based, and seasonal hydrochemical variations must therefore be incorporated into the sampling strategy. We studied the daily fluctuations of ion concentrations in the river and in a monitoring well located close to the river (distance $\approx 15 \mathrm{~m}$ ) using an automatic water sampler (6700, Teledyne ISCO Inc., USA) and subsequent chemical analysis in the laboratory. Hardness and bicarbonate display strong diurnal oscillations in the river (Fig. 6). These fluctuations are dampened in the adjacent monitoring wells. The other cation and anion concentrations vary only slightly and do not show periodic oscillations in the wells (Vogt et al., 2010a).

\subsection{Temperature surveys}

In recent years, temperature has become popular as a natural tracer for the quantification of exchange fluxes between surface-water bodies and aquifers (Anibas et al., 2009; Constantz et al., 2003; Hatch et al., 2006; Keery et al., 2007; Schmidt et al., 2006, 2007; Silliman and Booth, 1993). Distributed temperature sensing (DTS) is a rather new measurement technique enabling comprehensive investigations of temperature distributions along an optical fiber based on Raman scattering (e.g. Selker et al., 2006). The method allows temperature measurements along a several kilometer long fiber with a spatial resolution of $1 \mathrm{~m}$ and a temperature resolution $<0.1 \mathrm{~K}$ at a time resolution of $15 \mathrm{~min}$. By wrapping the fiber around a pole, the vertical resolution can be significantly increased (Fig. 7a). Vogt et al. (2010b) obtained high-resolution temperature profiles within the riverbed of the Thur River by installing such a wrapped pole (vertical resolution: $5 \mathrm{~mm}$ ). They analyzed the 
A:Schematic outline of the fiber-optic high-resolution vertical temperature profiler.
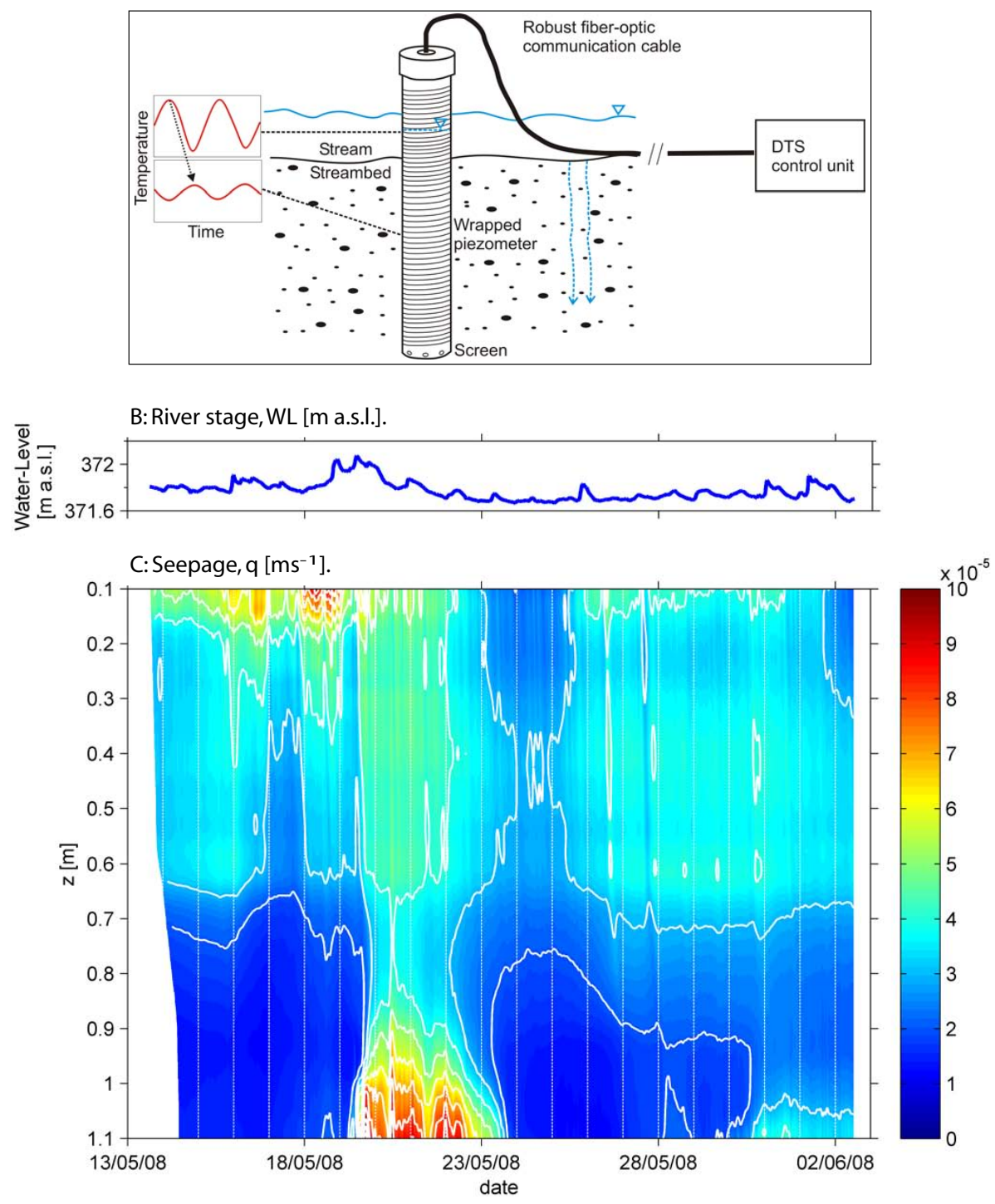

Fig. 7. Estimated apparent seepage fluxes compared to the river stage. (a) Distributed temperature sensing (DTS) for vertical profiles. (b) River stage of gauging station. (c) Calculated vertical seepage fluxes. Contourlines: isolines $1 \times 10^{-5} \mathrm{~ms}^{-1}$. Figure after Vogt et al. (2010b), modified.

resulting temperature time-series by nonstationary spectral methods, observing temporal variability of infiltration in response to water-level changes (Fig. 7b) and a vertical variation of seepage rates (Fig. 7c), which they attributed to multidimensional flow. Infiltration velocities are ranging from 2 to $5 \times 10^{-5} \mathrm{~m} \mathrm{~s}^{-1}$ when applying a 1-D solution, in which velocities of 4 to $5 \times 10^{-5} \mathrm{~m} \mathrm{~s}^{-1}$ is found in the upper sediment layers (depths up to $0.6 \mathrm{~m}$ ) and around $2 \times 10^{-5} \mathrm{~m} \mathrm{~s}^{-1}$ is found in the deeper layers (depths greater than $0.6 \mathrm{~m}$ ) respectively (Fig. 7c).

\section{Design of continuous monitoring and instrumentation}

Based on the results of the preliminary investigations discussed above, we designed a network of observation wells, organized in several transects and clusters, in order to monitor groundwater in the direct vicinity of Thur River. We aim to understand how key mechanisms of biogeochemical cycling of infiltrated river water are affected by the distance to the river, travel time within the subsurface, and characteristics of the river bank. This requires (1) installing monitoring-well transects oriented in the (assumed) direction of groundwater flow at locations with different riverbank characteristics, (2) the recording of quantities that allow the estimation of travel times, and (3) sampling strategies 
for water-quality parameters. Aspects pertaining to monitoring and instrumentation strategies of river morphodynamics and vegetation interactions at the site are described elsewhere (Pasquale et al., 2011). Also, detailed surveys using DTS in the river bed are reported elsewhere (Vogt et al., 2010b). In the following we will discuss (1) the design of the monitoring-well network and details of the installation, (2) hydraulic and geophysical tests performed in the monitoring-well transects, (3) the instrumentation of selected monitoring wells with continuously operating sensors, and (4) sampling strategies.

\subsection{Design of monitoring-well network}

A key objective of the groundwater monitoring is to study the transformation of river water into young groundwater. The river water is rich in oxygen and degradable organic carbon and it contains pollutants, while the young groundwater is depleted in oxygen and degradable organic carbon. This young groundwater may contain metabolites of the pollutants and is slightly more mineralized than the river water. At specific monitoring and sampling points, we want to (i) estimate travel times, (ii) determine transformation rates from concentration differences and time information, and (iii) help to develop a quantitative understanding of biogeochemical zonation and associated turnover of pollutants. The results concerning biogeochemistry and pollutant turnover will be presented elsewhere (Peter et al., 2011). Nonetheless, the monitoring-well network was designed with the goal of quantifying the turnover of solutes in mind.

Ideally, monitoring wells should be oriented along flow lines, thus allowing sampling of a wide range of groundwater ages, starting with very young (travel times of a few hours) hyporheic water. Hyporheic flow is seldom at steady state, so flow lines vary. Furthermore, riverbed sediments are reorganized during floods, leading to changed flowpaths in the subsurface. Even if these effects could be excluded, subsurface heterogeneity makes it difficult to predict flowpaths and travel-time distributions using regional groundwater level data alone. Water sampled in a particular monitoring well will therefore most likely bypass subsequent wells. Finally, very young hyporheic groundwater is difficult to access, since permanent installation of monitoring wells within the riverbed is impossible. Rather than focusing on a single transect of monitoring wells, we designed a network of several transects and clusters at different locations within our test site. Figure 2 shows all 86 monitoring wells installed at the site by January 2010.

All monitoring wells were installed with a dualtube soil sampling system using a direct-push machine (Geoprobe ${ }^{\circledR}$ 6620DT). The two-inch monitoring wells are made of HDPE or PVC pipes with $53 \mathrm{~mm}$ inner and about $60 \mathrm{~mm}$ outer diameter. They are mostly fully screened $(1 \mathrm{~mm}$ slot width) over the thickness of the gravel aquifer. Casing was installed over the thickness of the alluvial fines. One meter of casing was also added at the lower end extending into the underlying lacustrine clay. After extracting the outer direct-push tube of $83 \mathrm{~mm}$ diameter, filter gravel was added into the open space between the well tube and the open borehole up to a depth of approximately $1 \mathrm{~m}$ below ground. Bentonite was added to the top to prevent preferential infiltration along the well tube. Monitoring wells on overbanks terminate just below the ground surface within a concrete-cased PVC pipe of $300 \mathrm{~mm}$ diameter, capped at ground surface. The other monitoring wells end about $1 \mathrm{~m}$ above ground with standard well caps.

We grouped our monitoring wells in transects, which we will describe and discuss in the following. In a first step, we installed survey monitoring wells - forming hydrologic triangles or squares encompassing the full intended transect - to determine prevailing hydraulic gradients. We subsequently installed profiles of monitoring wells forming observation transects, following the hydraulic gradient determined by the initial monitoring wells. The spacing between the monitoring wells within the observation transect depends on the planned investigation methods and assumed travel times. For example, cross-borehole geophysical surveys require a maximum spacing in the range of the aquifer thickness, which is $4-7 \mathrm{~m}$ at our site. Practical issues such as bank stability and accessibility of the direct-push machine were also considered.

Besides a few individual monitoring wells, needed to determine the regional groundwater flow field and background values of hydrogeochemistry, the monitoring wells are arranged in the following transects and clusters:

\subsubsection{Pumping station transect A}

The river is channelized in the vicinity of the pumping station. The fluvial deposits on the overbanks are $2 \mathrm{~m}$ thick and the low-water channel is stabilized with riprap as revetment. The pumping well is located on the landside slope of the levee near the northern side channel (Fig. 2, A). A beaver dam in this side channel located $30 \mathrm{~m}$ upstream of the pumping station has locally increased the water level by $0.5 \mathrm{~m}$. Tracer tests have shown that the bed of the side channel is clogged in the reach upstream of the beaver dam. This transect is used as a reference to represent the channelized sections of the Thur River (Table 3, Fig. 2, A). The pump in the abstraction well is operated at a rate of $3.31 \mathrm{~s}^{-1}$ for $1 \mathrm{~h}$ (pumped volume $12 \mathrm{~m}^{3}$ ) in the morning and $2 \mathrm{~h}$ in the evening $\left(24 \mathrm{~m}^{3}\right)$.

\subsubsection{Forest transect B}

This transect (Fig. 2, B) starts on a gravel bar formed after restoration of the Thur River and extends into the mature alluvial forest. As indicated in Fig. 2, the overall hydraulic gradient along the transect is comparably small so that travel times of infiltrated river water may be longer than along transect A. Considering the regional hydrogeological situation, it 
can not be excluded that the groundwater at the north-western end of this transect consists of old groundwater rather than fresh-river infiltrate. At the south-eastern end of the transect, the morphologically active gravel bar is monitored, because we expect strong differences in water-mixing ratios of infiltrated river water to groundwater, hydrochemistry, and travel times between the two ends of the transect. As can be seen in Fig. 2, the observation wells are placed much more densely on the gravel bar than within the forest. The combination of transects A and B gives the opportunity to compare bank filtration at channelized and restored sections of the Thur River with similar geological properties (Fig. 2, A+B, see also Sect. 5.2).

\subsubsection{Central gravel bar cluster $\mathrm{C}$}

This cluster of individual monitoring wells is in the morphologically most active zone of the restored river reach. The monitoring wells are placed on a gravel bar that remains an island even at relatively high water levels. Currently, the thalweg is at the southern branch of the river, but within the time period since restoration in the year 2002, the main river course has also temporarily been north of the gravel bar. The river stage at the southern branch is about $20 \mathrm{~cm}$ higher than at the northern side, enforcing hyporheic flow through the gravel bar. Full inundation of the entire gravel bar occurs at $350 \mathrm{~m}^{3} \mathrm{~s}^{-1}$. Even though the surface of the gravel bar is covered by large pebbles, entrapped fines can be observed already at $10 \mathrm{~cm}$ depth. Because materials are mobilized during floods, the hydraulic conductivity within these active sedimentary deposits may change with time. In contrast to the other study areas, the monitoring wells are not aligned along a line, because the direction of flow through the gravel bar may change at small time scales according to different river stages, and due to morphological changes. Locations of the monitoring wells are chosen to represent different frequencies of inundation and different morphological features (e.g. the southern branch of the river actively cuts into the sediments), whereas the slope of the gravel bar is milder at the northern side.

\subsubsection{Downstream southern transect D}

This is a comparably short transect located on the southern overbank close to the central gravel bar (Fig. 2). Here, the thalweg of the river is very close to the overbank, which undergoes active erosion. We assume that clogging layers have not developed or are removed along the thalweg and thus speculate that river-water infiltration is not hindered in the vicinity of the transect $\mathrm{D}$. The hydraulic gradient between the river and the southern side channel is fairly steep suggesting that the youngest infiltrate is found along the chosen transect. This transect allows us to sample very young hyporheic water at monitoring wells on the overbank that otherwise would require installations within the river.

\subsubsection{Upstream southern transect E}

This transect (E in Fig. 2) exhibits the highest hydraulic gradient between the river and the side channel (Table 3) and is useful for artificial-tracer tests with limited time duration. A particular interest of such tracer experiments is to identify the direction of flow in comparison to the assumed hydraulic gradient and locations of local exfiltration into the southern side channel. We speculate that exfiltration zones are unevenly distributed forming hot spots. In comparison to the other transects and clusters, transect $\mathrm{E}$ includes several monitoring wells located very close to the draining southern side channel.

\subsection{Cross-borehole geophysical surveys on monitoring-well transects}

Compared to surface-based geophysical surveys, crossborehole measurements can provide subsurface information with higher resolution at depth in regions of specific interest. Doetsch et al. (2010a) combined data from cross-borehole seismic and ground-penetrating radar (GPR) travel times and ERT measurements for a hydrogeophysical characterization of the gravel aquifer at the Widen reference site (Fig. 1). GPR travel times sense variations in permittivity, which can be directly linked to porosity using petrophysical models (Lesmes and Friedman, 2005). Combining the porosity information with electrical resistivity models from ERT measurements allows estimation of the contribution of surface conductivity, which can be linked to the amounts of clay and silt material in the ground (Linde et al., 2006). At the restored reach near Neuenforn, cross-borehole GPR data were acquired between the densely spaced boreholes on transects A, B and C.

\subsection{Hydraulic surveys within the monitoring-well transects}

Slug tests are applied to estimate hydraulic conductivities of aquifers by measuring the recovery of hydraulic head in monitoring wells after a forced (nearly instantaneous) change. The recorded changes in hydraulic head over time are fitted to analytical solutions. Multi-level slug tests offer quantitative information about vertical and horizontal variations in hydraulic conductivity in the vicinity of individual monitoring wells (Butler, 1998). Compared to other techniques for hydraulic-conductivity estimation, slug tests offer advantages such as (i) low cost, (ii) simplicity, (iii) quick and easy application and data analysis, and (iv) small support volume (less than one decimeter around the test well) that allow estimating small-scale variability of aquifer properties (Butler, 1998). Pneumatic slug tests (injection of compressed air in a sealed monitoring well) are preferred over classic slug tests (dropping a weight into a well), because the former yield more accurate results in formations of high hydraulic conductivity (Butler, 1998). 
We performed multi-level rising-head pneumatic slug tests in selected monitoring wells in transect $\mathrm{A}$ and $\mathrm{B}$ using a double-packer system ( $0.5 \mathrm{~m}$ screen length) together with an air-tight well-head apparatus and a small-diameter pressure transducer (Druck PDCR 35/D-8070) connected to a data logger (Campbell Scientific CR800) with an acquisition rate of $10 \mathrm{~Hz}$. We followed best-practice recommendations (Butler et al., 2003; Zurbuchen et al., 2002) and processed our data according to Butler (1998), Butler et al. (2003), and McElwee and Zenner (1998) with the software AQTESOLVProfessional (www.aqtesolv.com). We applied the model of Bouwer and Rice (1976) for over-damped response data in unconfined aquifers, whereas for under-damped response data (with oscillatory behaviour), the model of Springer and Gelhar (1991) was used. In confined aquifers, we analyzed the response data with over-damped behaviour with the model of Bouwer and Rice (1976), whereas for the underdamped response data, the model of Butler (1998) was the most appropriate.

\subsection{Instrumentation of monitoring wells}

We conducted several water sampling campaigns to monitor bank filtration. First, we sampled all monitoring wells to select locations for detailed investigation. Based on these data, we installed combined sensor units for electrical conductivity, temperature, and pressure (DL/N70, STS AG, Switzerland; error of single measurement $\pm 2 \%$ for EC, $\pm 0.25 \mathrm{~K}$ for temperature, $\pm 0.1 \%$ for head) accompanied by sensor chains of electrical conductivity and temperature at different depths (e.g. 5TE, Decagon Devices, USA; error of single measurement $\pm 10 \%$ for EC, $\pm 1.0 \mathrm{~K}$ for temperature) in the river and in selected wells. In all transects, the monitoring well nearest to the river is equipped with such sensor chains consisting of at least two - in selected monitoring wells up to five monitoring levels over the full aquifer depth. With growing distance to the river along a transect, the number of monitored levels is reduced and successively concentrated to the topmost groundwater layer (upper meter of the aquifer). The sampling interval is $15 \mathrm{~min}$ which is adapted to the dynamics of the river.

Selected monitoring-wells in locations next to the river are equipped with multi-level sensing and sampling devices in a first step. In a second step, sensors are installed to continuously stream data via wireless data transfer techniques (Barrenetxea et al., 2008; Beutel et al., 2007), allowing real-time processing and analysis of these proxy data to enable time and depth-optimized sampling.

\section{Results}

\subsection{Geodetic surveys, bathymetry and hydraulic modeling}

We calibrated and validated the hydraulic model BASEMENT (Vetsch et al., 2005, http://www.basement.ethz.ch/) following the approach mentioned in Sect. 3.1 for each available digital elevation model (DEM). Subsequently, we simulated river stages for flow conditions ranging from the minimum recorded discharge up to the one that completely inundates the island. Given the coarse grain-size distribution of the alluvial material (Pasquale et al., 2011), the water-table fluctuations are expected to penetrate the gravel bar with almost no delay with respect to hydrograph dynamics. This implies quasi steady-state flow within the gravel bar. As a simple estimate, we inferred the groundwater table in the gravel bed for each point of the island (Fig. 8). After having installed our monitoring wells in cluster $\mathrm{C}$, we compared the interpolated heads to measured data of the monitoring wells in cluster C. Figure 8d shows this comparison for well R034, indicating a fairly high accuracy of the interpolation even under dynamic conditions (root mean-square error $80 \mathrm{~mm}$ ). This implies that hydraulic modeling of the river at the site is not only useful to analyze fluvial hydrodynamics, but also predicts dynamics of hyporheic water tables. Additional information about hydraulic conductivities is needed to estimate hyporheic flow velocities and travel times.

\subsection{Cross-borehole geophysical surveys}

Cross-borehole GPR travel-time tomography was performed along transect A (Fig. 2) to estimate relative variations in porosity (Fig. 9). Radar travel-time inversion was first used to estimate the electrical-permittivity distribution, which was then transformed into estimates of porosity. These porosity estimates were obtained using the petrophysical model of Linde et al. (2006) with the parameters chosen by Doetsch et al. (2010a) at the Widen site (see Fig. 1). The porosities representing meter-scale averages vary between $16 \%$ and $23 \%$, and a lower-porosity layer is clearly imaged in the middle of the gravel aquifer (Fig. 9).

For cross-borehole GPR, it is important to have densely spaced boreholes fully penetrating the layers of interest. The ratio of borehole separation and the depth range of interest should preferably be smaller than one. The areas of interest should thus be defined on the basis of geological knowledge and surface-based geophysical measurements before installing an appropriate dense network of monitoring wells. For the processing of cross-borehole GPR data, it is essential to either have almost perfectly vertical boreholes or measure borehole deviations to obtain accurate (within a few $\mathrm{cm}$ ) information about lateral positions of the antennas in the ground. 

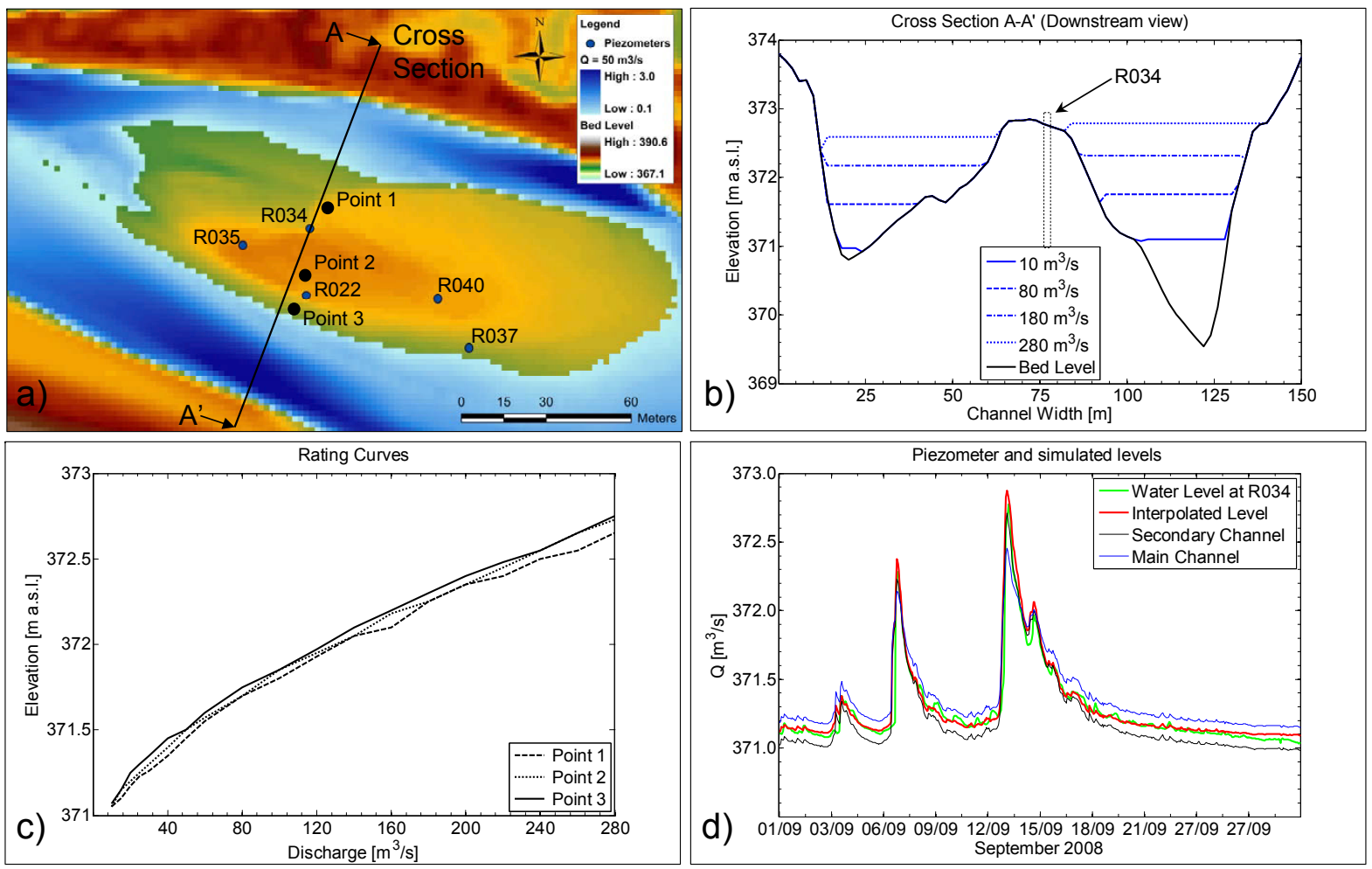

Fig. 8. Cross section across the central gravel bar (transect $\mathrm{C}$ in Fig. 2): (a) plan view; (b) profile of surface elevation (m a.s.1.) and water depth $(\mathrm{m})$ as function of river discharge shown in flow direction; (c) corresponding rating curves, (d) comparison between measured and interpolated groundwater heads in monitoring well R034.

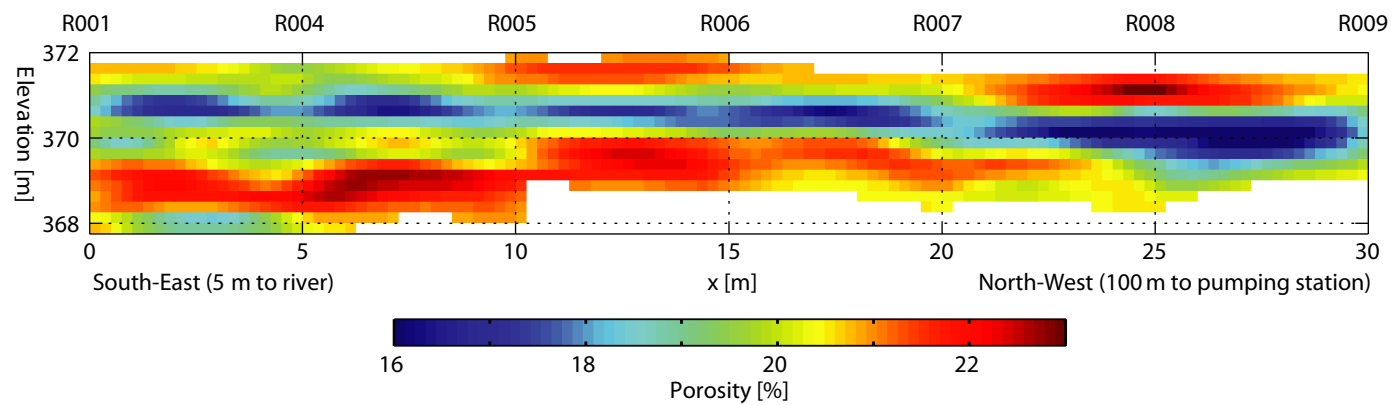

Fig. 9. Porosity distribution along the pumping-station transect (transect A in Fig. 2) obtained by cross-borehole georadar travel-time tomography. A continuous low-porosity layer is imaged across the entire profile between two higher-porosity subhorizontal layers. Note that the porosities represent average porosities on the m-scale and that the absolute values might be slightly down or upward biased given the uncertainty of the parameter values chosen for the petrophysical transformation.

\subsection{Hydraulic surveys}

Figure 10 illustrates the hydraulic-conductivity distribution along transect A (Fig. 2) obtained by the multi-level slug tests described in Sect. 4.3. In total, 51 measurements of hydraulic conductivity $K$ were performed in the part of transect A next to the river $(5-30 \mathrm{~m})$. They revealed less heterogeneity than commonly expected for fluvial gravel deposits. The geometric mean was $3.1 \times 10^{-3} \mathrm{~m} \mathrm{~s}^{-1}\left(\approx 10^{-2.5} \mathrm{~m} \mathrm{~s}^{-1}\right)$ and the variance of $\log _{10}$ hydraulic conductivity was 0.2 . These results agree with values obtained at other test sites in the Thur Valley (Diem et al., 2010), indicating that our monitoringwell transects might be geologically representative for the entire Thur Valley. To obtain the vertical cross section of the hydraulic conductivity $K$ in Fig. 10, we interpolated the $K$-measurements by kriging assuming an anisotropy ratio of ten and a linear variogram. The lowest $K$-values are observed at the aquifer bottom, while higher $K$-values are 


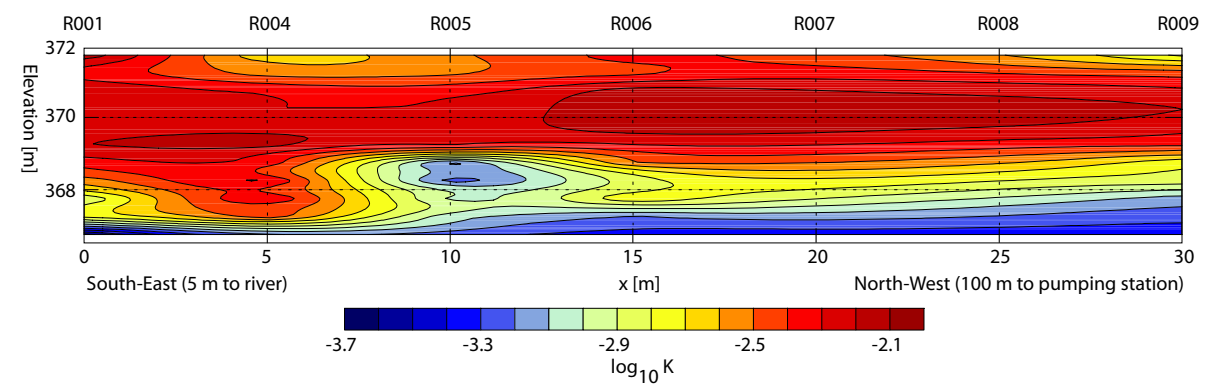

Fig. 10. Hydraulic-conductivity distribution along the pumping-station transect (transect A in Fig. 2) obtained by multi-level slug tests performed in fully penetrating monitoring wells along the transect A. A continuous high hydraulic-conductivity layer is imaged in the upper aquifer, whereas the lower part of the aquifer is characterized by lower hydraulic conductivities.

found in the center of the aquifer (Fig. 10). $K$-values range between $2.3 \times 10^{-4} \mathrm{~m} \mathrm{~s}^{-1}\left(\approx 10^{-3.7} \mathrm{~m} \mathrm{~s}^{-1}\right.$, labeled blue in Fig. 10) and $7.4 \times 10^{-3} \mathrm{~m} \mathrm{~s}^{-1}\left(\approx 10^{-2.1} \mathrm{~m} \mathrm{~s}^{-1}\right.$, labeled red in Fig. 10).

\subsection{Hydrochemical sampling and sensing}

Figure 11 shows time series of the river water level (A) and electrical conductivity (B) in the Thur River and in monitoring well R042 (transect $\mathrm{A}, \approx 15 \mathrm{~m}$ from the river). The figure shows a clear correspondence between electricalconductivity (EC) signals in the river and in the monitoring well. As reported in previous studies (Cirpka et al., 2007; Vogt et al., 2009, 2010a), EC in the Thur River drops in response to precipitation in the upper catchment, which also causes high river water stages (see the correspondence of water table and low EC during flood events in Fig. 11). The EC signal is propagated into the aquifer by advective-dispersive transport and is slightly modified by water-rock interactions. We analyze the time series of EC in the river and all monitoring wells equipped with EC sensors by nonparametric deconvolution (Cirpka et al., 2007). This method yields the transfer function $g(\tau)$ of EC between the river and the observation well without relying on a particular functional form, but assuming stationarity of $g(\tau)$. The transfer function may be understood as the outcome of a virtual tracer test with pulse-like injection.

The integral of the transfer function can be interpreted as the recovery rate of the EC signal, possibly quantifying the mixing ratio of fresh river-water infiltrate in the mixture with old groundwater. The normalized transfer function $p(\tau)=g(\tau) / \int_{0}^{\infty} g\left(\tau_{*}\right) d \tau_{*}$ is the probability density function of travel time for the transfer of EC from the river to the observation well. Figure $11 \mathrm{c}$ illustrates the transfer function inferred from the EC time series shown in Fig. 11b. A detailed discussion of EC time series obtained at the site, including elaborations on diurnal fluctuations, is given by Vogt et al. (2010a).
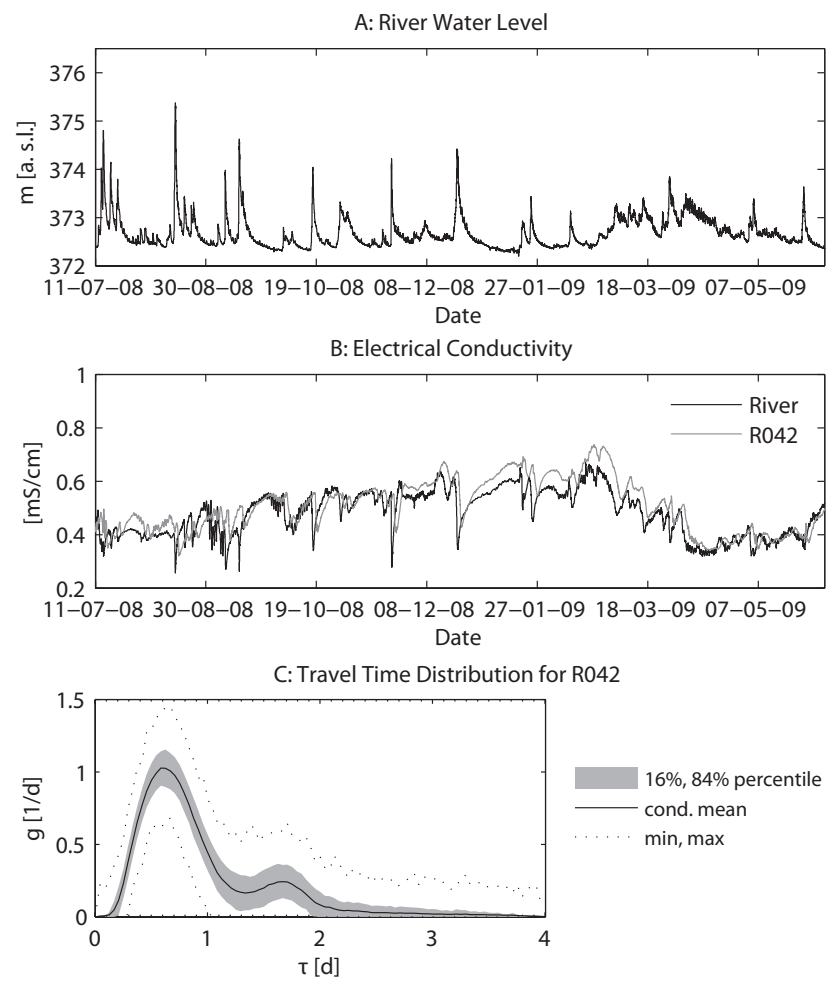

Fig. 11. River water level (A) and electrical conductivity fluctuations (B) in River Thur and a near-river monitoring well (R042) in the forest transect (transect B in Fig. 2). Transfer function (C) between the Thur River and monitoring well R042 obtained by deconvolution of the electrical-conductivity time series. Figure after Vogt et al. (2010a), modified.

\section{Discussion and conclusions}

We have presented an instrumentation strategy for the assessment of bank-filtration processes in a partly restored river reach. The strategy consists of (1) preliminary surveys characterizing primarily structural properties of the river and the subsurface, (2) the design, instrumentation, and operation of monitoring-well transects, and (3) data analysis by modeling. 
While the studies have been performed to address waterquality issues of river restoration, this work focuses on physical properties and processes. Particular emphasis has been placed on selecting and instrumenting monitoring-well transects and clusters in the channelized and restored parts of the river reach.

The hydro-chemical properties of the infiltrating river water change during and after infiltration with a continued transformation according to its travel time in the aquifer. To study the full range of transformation, it is important to identify locations with freshly infiltrated water and install transects of observation points that approximately follow the flowpaths. This was the major incentive of instrumenting transects A, B, and D (Fig. 2), as they differ in hydraulic gradient, sampled groundwater age, and biogeochemical gradients.

In natural or restored river reaches with highly variable river morphology and dynamic flow regime, it may be impossible to identify points of pronounced infiltration and follow the direction of subsurface flow. Under such conditions, one may need to give up the idea of approximately following a water parcel. Instead, the use of monitoring-well clusters like cluster C (Fig. 2) - may become more appropriate. Enhanced erosion and deposition in restored river reaches lead to permanently changing river morphology and thus add to the complexity of maintaining continuous monitoring, and increase the related efforts and costs significantly. To protect monitoring wells in the floodplain, selected wells were constructed using a below-ground enclosure design. Several monitoring wells located on uncolonized and colonized gravel bars were frequently buried by sediments. It is therefore important to accurately locate (within a few $\mathrm{cm}$ ) all monitoring wells in the river corridor right after installation, for example, with a high-precision differential GPS. Online sensing prevents losing complete time series acquired in such harsh environments.

The first results obtained at our site indicate that groundwater tables between river branches or between the river and side channels can be approximated rather well by interpolating surface-water levels, even under dynamic conditions. This implies a good hydraulic connection between surface water and groundwater. We have gained predictive capabilities with respect to groundwater levels by the calibration of a river-hydraulic model. The data needed for this model are the bathymetry of the river and side channels, the river hydrograph obtained at a river station downstream of our site, and individual river-stage or shore-line measurements at known river discharge for calibration. This procedure can be transferred to other sites with braided rivers or connected rivers and side channels.

Subtracting the estimated groundwater tables from measurements of land-surface topography yields the distance to the groundwater table, which may be an important parameter for the development of riparian vegetation and thus contributes to the overall ecological evaluation of river restoration. Missing groundwater table dynamics in the presence of fluctuating river stages would be a clear indication of lacking connections between river and groundwater. However, synchronous river and groundwater head signals alone are an insufficient indicator to quantify river-groundwater exchange (counter examples at the Thur River are given by Vogt et al., 2009). Measurements of exchange fluxes are also needed, which are difficult to obtain (Kalbus et al., 2006).

At the Thur River, travel times and mixing ratios between fresh river-water infiltrate and old groundwater can be inferred from time series of electrical conductivity (Cirpka et al., 2007; Vogt et al., 2009, 2010a). Travel times and mixing ratios are much better indicators of river-groundwater exchange than hydraulic gradients. Travel times and hydraulic gradients are linked by hydraulic conductivity and porosity, which we have constrained in our monitoring-well transects by hydraulic and geophysical surveys. The deconvolution procedure of Cirpka et al. (2007), applied to infer the traveltime distributions, requires time series with several events of strong EC fluctuations. This implies a need for continuous measurements rather than individual sampling campaigns. Deployment of a sufficient number of sensors is thus crucial to gain system understanding. Extended analysis of the EC data to address changes of travel-time distributions over time will require the development of non-stationary deconvolution methods.

Field investigations in the past have often been limited by instrumentation costs and insufficient resolution of data in time and/or space. New developments in environmental sensing (Barrenetxea et al., 2008; Beutel et al., 2007; Trubilowicz et al., 2009) reduce monitoring network hardware and operation costs significantly and thus allow two and three-dimensional online sensing of EC, water temperature and hydraulic head with sensor units or multi-level sensor chains. Wireless data transfer reduces data losses and allows high resolution sensing of these proxy hydrological parameters at reasonable costs (Barrenetxea et al., 2008; Beutel et al., 2007; Nadeau et al., 2009; Trubilowicz et al., 2009). Additionally, data handling can be partially automated and thereby reduce labor costs (Michel et al., 2009; Schneider et al., 2011; Wombacher and Schneider, 2010). The combination of temporary deployments of such research monitoring networks (local scale, short to mid-term, problem-orientated and process-focused data sets) with governmental long-term monitoring networks (regional scale, durable design, continuous data records) is very promising.

Besides EC, we have also performed continuous monitoring of groundwater head and temperature. These data are currently under evaluation and are not discussed in the present paper. Continuous data streams of chemical parameters could potentially be of high value. Costs and stability of related sensors hinder, so far, massive deployment, so that chemical measurements at our site have been restricted to samples. The assessment of mixing ratios and travel times at individual points and of prevailing hydraulic gradients is insufficient to determine groundwater flowpaths. The latter 
are strongly affected by subsurface heterogeneity (e.g. Ptak and Teutsch, 1994) and may not fully coincide with hydraulic gradients. In a dynamic riparian system, hydraulic gradients and groundwater flowpaths vary in accordance to variable forcing created by fluctuations of surface-water level. This has consequences on the performance of our monitoring-well transects which were intended to follow flowpaths aproximately. We have oriented our monitoring-well transects in the direction of the hydraulic gradient determined from a few preliminary wells at times of low river stage. Our transects do not cover individual groundwater-flow lines at all times, but we are convinced that our strategy is superior to placing monitoring-well transects perpendicular to the direction of the river, as done in the vast majority of studies on bank filtration, hyporheic exchange, and riparian-zone mixing (Woessner, 2000).

For investigation of aquifer thickness and sediment structures we have used geophysical surveying. For a quantitative understanding of the groundwater flow field and associated solute transport, hydraulic parameters must be attached to the identified sedimentological structures, which we have initiated by hydraulic surveys. Boundary conditions are obtained from the river-hydraulic model and monitoring data of the river and the side channels. The ultimate goal is to integrate all available information into a 3-D groundwater flowand-transport model of the site that can simulate and forecast observed head and EC data in the monitoring wells. We are in the process of developing such a model. For the assessment of bank filtration, we recommend recording multi-level sensor data focusing on EC directly at river banks (Vogt et al., 2010a). The major challenges in monitoring bank filtration are (i) to choose locations with sedimentation-erosion equilibrium for monitoring-well transects, so that monitoring wells and sensors survive floods without getting eroded or covered by sediments, (ii) to choose transects with a significant hydraulic gradient in groundwater, (iii) to install costeffective sensors, so that 2-D or 3-D monitoring is feasible and (iv) to stream data, for example via state of the art wireless technology, so that failure or loss of a sensor does not result in a complete loss of data. Benefits of online monitoring systems are the flexible timing for sampling at specific locations and times informed by the proxy data that reflect the status of the system in the surroundings of a monitoringwell transect.

Acknowledgements. This study was mainly financed by the Competence Center Environment and Sustainability (CCES) of the ETH domain in the framework of the RECORD project (Assessment and Modeling of Coupled Ecological and Hydrological Dynamics in the Restored Corridor of a River - Restored Corridor Dynamics, http://www.cces.ethz.ch/projects/nature/Record). We would also like to acknowledge funding from the Swiss National Science Foundation. We thank Andreas Raffainer, Richard Fankhauser, and Peter Gäumann of the Eawag workshop as well as Romeo Favero, Ulrich Göttelmann, Robert Holzschuh, Andreas Scholtis, and Marco Baumann from AfU, Canton Thurgau and Urs Spychiger,
Franz Bieler, Kurt Nyfenegger, and Matthias Oplatka from AWEL, Canton Zürich for their support and close cooperation. We would also like to thank Mirco Pessognelli, Ilaria Coscia and Fabian Hurter for their help in acquiring the ERT and GPR profiles. Reviews of Bayani Cardenas and Christian Anibas helped to improve the manuscript.

Edited by: E. Durisch-Kaiser

\section{References}

Anibas, C., Fleckenstein, J., Volze, N., Buis, K., Verhoeven, R., Meire, P., and Batelaan, O.: Transient or steady state? Using vertical temperature profilest o quantify groundwatersurfacewater exchange, Hydrol. Process., 23, 2165-2177, doi:10.1002/hyp.7289, 2009.

BAFU: Hydrologischer Atlas der Schweiz, Bundeamt für Umwelt, Bern, 2010.

Barrenetxea, G., Ingelrest, F., Schaefer, G., and Vetterli, M.: The Hitchhiker's Guide to Successful Wireless Sensor Network Deployments, Sensys'08: Proceedings of the 6th ACM Conference on Embedded Networked Sensor Systems, 43-56, 2008.

Battin, T. J. and Sengschmitt, D.: Linking sediment biofilms, hydrodynamics, and river bed clogging: evidence from a large river, Microb. Ecol., 37, 185-196, doi:10.1007/s002489900142, 1999.

Baumann, M., Jordan, P., Hoehn, E., and Geisser, H.: Ein neues Grundwassermodell für das Thurtal. Mitteilungen der Thurgauischen Naturforschenden Gesellschaft, Band 63, Frauenfeld, 240, 2009.

Beres, M., Huggenberger, P., Green, A. G., and Horstmeyer, H.: Using two- and three-dimensional georadar methods to characterize glaciofluvial architecture, Sediment. Geol. 129, 1-24, 1999.

Beutel, J., Dyer, M., Lim, R., Plessl, C., Wohrle, M., Yucel, M., and Thiele, L.: Automated wireless sensor network testing, INSS 07: Proceedings of the Fourth International Conference on Networked Sensing Systems, 303-303, 2007.

Bosma, T. N. P., Ballemans, E. M. W., Hoekstra, N. K., teWelscher, R. A. G., Smeenk, J. G., Schraa, G., and Zehnder, A. J. B.: Biotransformation of organics in soil columns and an infiltration area, Ground Water, 34, 49-56, 1996.

Bourg, A. C. M. and Bertin, C.: Biogeochemical processes during the infiltration of river water into an alluvial aquifer, Environ. Sci. Technol., 27, 661-666, 1993.

Bouwer, H. and Rice, R. C.: Slug test for determining hydraulic conductivity of unconfined aquifers with completely or partially penetrating wells, Water Resour. Res., 12, 423-428, 1976.

Brunke, M. and Gonser, T.: The ecological significance of exchange processes between rivers and groundwater, Freshwater Biol., 37, 1-33, 1997.

Butler, J. J.: The Design, Performance and Analysis of Slug Tests, Lewis, Boca Raton, 252, 1998.

Butler, J. J., Garnett, E. J., and Healey, J. M.: Analysis of slug tests in formations of high hydraulic conductivity, Ground Water, 41, 620-630, 2003.

BUWAL: Wegleitung Grundwasserschutz, Bundesamt für Umwelt, Wald und Landschaft, Bern, 2004.

Cardenas, M. B., Wilson, J. L., and Zlotnik, V. A.: Impact of heterogeneity, bed forms, and stream curvature on subchannel hyporheic exchange, Water Resour. Res., 40, 14-26, 2004. 
Cirpka, O. A., Fienen, M. N., Hofer, M., Hoehn, E., Tessarini, A., Kipfer, R., and Kitanidis, P. K.: Analyzing bank filtration by deconvoluting time series of electric conductivity, Ground Water, 45, 318-328, 2007.

Constantz, J., Cox, M. H., and Su, G. W.: Comparison of heat and bromide as ground water tracers near streams, Ground Water, 41, 647-656, 2003.

Coscia, I., Greenhalgh, S., Linde, N., Doetsch, J., Günther, T., Vogt, T., and Green, A.: 3-D crosshole apparent resistivity monitoring and static inversion of a coupled river-aquifer system, Geophysics, 76, G49-G59, doi:10.1190/1.3553003, 2011.

Diem, S., Vogt, T., and Hoehn, E.: Spatial characterization of hydraulic conductivity in alluvial gravel-and-sand aquifers: Which method?, Grundwasser, 15, 241-251, 2010.

Doetsch, J., Linde, N., Coscia, I., Greenhalgh, S. A., and Green, A. G.: Zonation for 3D aquifer characterization based on joint inversion of multimethod crosshole geophysical data, Geophysics, 75, G53-G64, doi:10.1190/1.3496476, 2010a.

Doetsch, J., Coscia, I., Greenhalgh, S., Linde, N., Green, A., and Günther, T.: The borehole-fluid effect in electrical resistivity imaging, Geophysics, 75, F107-F114, doi:10.1190/1.3467824, 2010b.

Doetsch, J., Linde, N., Pessognelli, M., Green, A. G., and Günther, T.: Constraining 3-D electrical resistivity inversions with GPR data for improved aquifer characterization, J. Appl. Geophys., doi:10.1016/j.jappgeo.2011.04.008, in press, 2011.

Eckert, P., Lamberts, R., and Wagner, C.: The impact of climate change on drinking water supply by riverbank filtration, Water Sci. Technol., 8, 319-324, 2008.

Edmaier, K., Burlando, P., and Perona, P.: Mechanisms of vegetation uprooting by flow in alluvial non-cohesive sediment, Hydrol. Earth Syst. Sci., 15, 1615-1627, doi:10.5194/hess-15-16152011, 2011.

European Commission: Directive 2000/60/EC of the European Parliament and of the Council establishing a framework for Community action in the field of water policy, Official Journal of the European Community, L327, 1-72, 2000.

Fleckenstein, J. H., Niswonger, R. G., and Fogg, G. E.: Riveraquifer interactions, geologic heterogeneity, and low-flow management, Ground Water, 44, 837-852, 2006.

Gooseff, M. N., Anderson, J. K., Wondzell, S. M., LaNier, J., and Haggerty, R.: A modelling study of hyporheic exchange pattern and the sequence, size, and spacing of stream bedforms in mountain stream networks, Oregon, USA, Hydrol. Process., 19, 29152929, 2005.

GSchG: Gewaesserschutzgesetz, Bundesgesetz über den Schutz der Gewässer, Schweiz, 814.20, 30, 1991.

GSchV: Gewaesserschutzverordnung, Bundesgesetz über den Schutz der Gewässer, Schweiz, 814.201, 60, 1998.

Günther, T., Rucker, C., and Spitzer, K.: Three-dimensional modelling and inversion of dc resistivity data incorporating topography - II. Inversion, Geophys. J. Int., 166, 506-517, 2006.

Harvey, J. W. and Bencala, K. E.: The effect of streambed topography on surface-subsurface water exchange in mountain catchments, Water Resour. Res., 29, 89-98, 1993.

Hatch, C. E., Fisher, A. T., Revenaugh, J. S., Constantz, J., and Ruehl, C.: Quantifying surface water-groundwater interactions using time series analysis of streambed thermal records: Method development, Water Resour. Res., 42, 14-28, 2006.
Hiscock, K. M. and Grischek, T.: Attenuation of groundwater pollution by bank filtration, J. Hydrol., 266, 139-144, 2002.

Hoehn, E. and Scholtis, A.: Exchange between a river and groundwater, assessed with hydrochemical data, Hydrol. Earth Syst. Sci., 15, 983-988, doi:10.5194/hess-15-983-2011, 2011.

Huggenberger, P., Hoehn, E., Beschta, R., and Woessner, W.: Abiotic aspects of channels and floodplains in riparian ecology, Workshop on River in the Landscape: Riparian and Groundwater Ecology, Blackwell Science Ltd, Kastanienbaum, Switzerland, 407-425, 1996.

Jacobs, L. A., von Gunten, H. R., Keil, R., and Kuslys, M.: Geochemical changes along a river-groundwater infiltration flow path - Glattfelden, Switzerland, Geochim. Cosmochim. Acta, 52, 2693-2706, 1988.

Kalbus, E., Reinstorf, F., and Schirmer, M.: Measuring methods for groundwater - surface water interactions: a review, Hydrol. Earth Syst. Sci., 10, 873-887, doi:10.5194/hess-10-873-2006, 2006.

Kalbus, E., Schmidt, C., Molson, J. W., Reinstorf, F., and Schirmer, M.: Influence of aquifer and streambed heterogeneity on the distribution of groundwater discharge, Hydrol. Earth Syst. Sci., 13, 69-77, doi:10.5194/hess-13-69-2009, 2009.

Keery, J., Binley, A., Crook, N., and Smith, J. W. N.: Temporal and spatial variability of groundwater-surface water fluxes: Development and application of an analytical method using temperature time series, J. Hydrol., 336, 1-16, 2007.

Kipfer, R., Aeschbach-Hertig, W., Peeters, F., and Stute, M.: Noble gases in lakes and ground waters, in: Noble Gases in Geochemistry and Cosmochemistry, edited by: Porcelli, D., Ballentine, C. J., and Wieler, R., Reviews in Mineralogy and Geochemistry, 615-700, 2002.

Kondolf, G. M.: Lessons learned from river restoration projects in California, Aquat. Conserv., 8, 39-52, 1998.

Lesmes, D. P. and Friedman, S. P.: Relationships between the electrical and hydrogeological properties of rocks and soils, in: Hydrogeophysics, editec by: Rubin, Y. and Hubbard, S. S., Springer, 87-128, 2005.

Linde, N., Binley, A., Tryggvason, A., Pedersen, L. B., and Revil, A.: Improved hydrogeophysical characterization using joint inversion of cross-hole electrical resistance and groundpenetrating radar traveltime data, Water Resour. Res., 42, W12404, doi:10.1029/WR005131, 2006.

Linde, N., Doetsch, J., Jougnot, D., Genoni, O., Dürst, Y., Minsley, B. J., Vogt, T., Pasquale, N., and Luster, J.: Self-potential investigations of a gravel bar in a restored river corridor, Hydrol. Earth Syst. Sci., 15, 729-742, doi:10.5194/hess-15-729-2011, 2011.

Lunt, I. A., Bridge, J. S., and Tye, R. S.: A quantitative threedimensional depositional model of gravelly braided rivers, Sedimentology, 51, 377-414, 2004.

McElwee, C. D. and Zenner, M. A.: A nonlinear model for analysis of slug-test data, Water Resour. Res., 34, 55-66, 1998.

Merkli, B.: Untersuchungen über Mechanismen und Kinetik der Elimination von Bakterien und Viren im Grundwasser, Diss. ETH Nr. 5420, 1975.

Miall, A. D.: Description and interpretation of fluvial deposits - a critical perspective, Sedimentology, 42, 379-384, 1995.

Michel, S., Salehi, A., Luo, L., Dawes, N., Aberer, K., Barrenetxea, G., Bavay, M., Kansal, A., Kumar, K. A., Nath, S., Parlange, M., Tansley, S., van Ingen, C., Zhao, F., and Zhou, Y.: Environmental Monitoring 2.0, IEEE 25th International Conference on Data 
Engineering, 1-3, 1507-1510, 2009.

Nadeau, D. F., Brutsaert, W., Parlange, M. B., Bou-Zeid, E., Barrenetxea, G., Couach, O., Boldi, M. O., Selker, J. S., and Vetterli, M.: Estimation of urban sensible heat flux using a dense wireless network of observations, Environ. Fluid Mech., 9, 635-653, 2009.

Orghidan, T.: Ein neuer Lebensraum des unterirdischen Wassers: der hyporheische Biotop, Arch. Hydrobiol., 55, 392-414, 1959.

Pasquale, N., Perona, P., Schneider, P., Shrestha, J., Wombacher, A., and Burlando, P.: Modern comprehensive approach to monitor the morphodynamic evolution of a restored river corridor, Hydrol. Earth Syst. Sci., 15, 1197-1212, doi:10.5194/hess-151197-2011, 2011.

Peter, S., Rechsteiner, R., Lehmann, M. F., Brankatschk, R., Vogt, T., Traber, J., Huber, B., Wehrli, B., Tockner, K., and DurischKaiser, E.: Nitrate removal in a restored riparian groundwater system: The role of vegetation-soil-groundwater coupling, J. Biogeochem., submitted, 2011.

Ptak, T. and Teutsch, G.: Forced and natural gradient tracer test in a highly neterogeneous porous aquifer - Instrumentation and measurements, J. Hydrol., 159, 79-104, 1994.

Regli, C., Rauber, M., and Huggenberger, P.: Analysis of aquifer heterogeneity within a well capture zone, comparison of model data with field experiments: A case study from the river Wiese, Switzerland, Aquat. Sci., 65, 111-128, 2003.

Samaritani, E., Shrestha, J., Fournier, B., Frossard, E., Gillet, F., Guenat, C., Niklaus, P. A., Pasquale, N., Tockner, K., Mitchell, E. A. D., and Luster, J.: Heterogeneity of soil carbon pools and fluxes in a channelized and a restored floodplain section (Thur River, Switzerland), Hydrol. Earth Syst. Sci., 15, 1757-1769, doi:10.5194/hess-15-1757-2011, 2011.

Schälchli, U.: The clogging of coarse gravel river beds by fine sediments, Hydrobiologia, 235-236, 189-197, doi:10.1007/BF00026211, 1992.

Schälchli, U.: Geschiebehaushalt im Thurgebiet, Wasser Energie Luft, 100, 23-28, 2008.

Schäppi, B., Perona, P., Schneider, P., and Burlando, P.: Integrating river cross section measurements with Digital Terrain Models for improved flow modelling applications, Comput. Geosci., 36, 707-716, 2010.

Schmidt, C., Bayer-Raich, M., and Schirmer, M.: Characterization of spatial heterogeneity of groundwater-stream water interactions using multiple depth streambed temperature measurements at the reach scale, Hydrol. Earth Syst. Sci., 10, 849-859, doi:10.5194/hess-10-849-2006, 2006.

Schmidt, C., Conant, B., Bayer-Raich, M., and Schirmer, M.: Evaluation and field-scale application of an analytical method to quantify groundwater discharge using mapped streambed temperatures, J. Hydrol., 347, 292-307, 2007.

Schneider, P., Wombacher, A., and Seibert, J.: Wanted: better data models for environmental observations, Ms. Ref. No.: STOTEND-11-01834, Sci. Total Environ., submitted, 2011.

Schwarzenbach, R. P. and Westall, J.: Transport of non-polar organic compounds from surface-water to groundwater - laboratory sorption studies, Environ. Sci. Technol., 15, 1360-1367, 1981.

Schwarzenbach, R. P., Giger, W., Hoehn, E., and Schneider, J. K.: Behavior of organic-compounds during infiltration of river water to groundwater - Field studies, Environ. Sci. Technol., 17,
472-479, 1983.

Schwarzenbach, R. P., Escher, B. I., Fenner, K., Hofstetter, T. B., Johnson, C. A., von Gunten, U., and Wehrli, B.: The challenge of micropollutants in aquatic systems, Science, 313, 1072-1077, 2006.

Seiz, G. and Foppa, N.: Nationales Klima-Beobachtungssystem (GCOS Schweiz), Bundesamt für Meteorologie und Klimatologie, MeteoSchweiz und ProClim, Bern, 2007.

Selker, J. S., Thevenaz, L., Huwald, H., Mallet, A., Luxemburg, W., de Giesen, N. V., Stejskal, M., Zeman, J., Westhoff, M., and Parlange, M. B.: Distributed fiber-optic temperature sensing for hydrologic systems, Water Resour. Res., 42, W12202, doi:10.1029/2006WR005326, 2006.

Shankar, V., Eckert, P., Ojha, C., and Konig, C. M.: Transient threedimensional modeling of riverbank filtration at Grind well field, Germany, Hydrogeol. J., 17, 321-326, 2009.

Silliman, S. E. and Booth, D. F.: An anlysis of time-series measurements of sediment temperature for identification of gaining vs losing portions of Juday-creek, Indiana, J. Hydrol., 146, 131148, 1993.

Springer, R. K. and Gelhar, L. W.: Characterization of large-scale aquifer heterogeneity in glacial outwash by analysis of slug tests with oscillatory response, Report 91-4034, US Geological Survey, Cape Cod, 1991.

Stanford, J. A. and Ward, J. V.: The hyporheic habitat of river ecosystems, Nature, 335, 64-66, 1988.

Stanford, J. A. and Ward, J. V.: An ecosystem perspective of alluvial rivers - connectivity and the hyporheic corridor, J. N. Am. Benthol. Soc., 12, 48-60, 1993.

Stauffer, F. and Dracos, T.: Experimental and numerical study of water and solute infiltration in layered porous media, J. Hydrol., 84, 9-34, 1986.

Storey, R. G., Howard, K. W. F., and Williams, D. D.: Factors controlling riffle-scale hyporheic exchange flows and their seasonal changes in a gaining stream: A three-dimensional groundwater flow model, Water Resour. Res., 39, 17, 2003.

Strahler, A. N.: Hypsometric (area-altitude) analysis of erosional topography, Bull. Geol. Soc. Am. 63, 1117-1142, doi:10.1130/0016-7606, 1952.

SVGW: Jahrbuch 2003/2004, SVGW, Zürich, 2004.

SVGW: Empfehlungen - Revitalisierung im Einflussbereich von Trinkwasserfassungen, 2007.

Triska, F. J., Kennedy, V. C., Avanzino, R. J., Zellweger, G. W., and Bencala, K. E.: Retention and transport of nutrients in a 3rdorder stream in norhtwestern California - Hyporheic processes, Ecology, 70, 1893-1905, 1989.

Triska, F. J., Duff, J. H., and Avanzino, R. J.: Patterns of hydrological exchange and nutrient transformation in the hyporheic zone of a gravel-bottom stream - Examining terrestrial aquatic linkages, Freshwater Biol., 29, 259-274, 1993a.

Triska, F. J., Duff, J. H., and Avanzino, R. J.: The role of water exchange between a stream channel and its hyporheic zone in nitrogen cycling at the terrestrial aquatic interface, Hydrobiologia, 251, 167-184, 1993b.

Trubilowicz, J., Cai, K., and Weiler, M.: Viability of motes for hydrological measurement, Water Resour. Res., 45, W00D22, doi:10.1029/2008WR007049, 2009.

Tufenkji, N., Ryan, J. N., and Elimelech, M.: The promise of bank filtration, Environ. Sci. Technol., 36, 422A-428A, 2002. 
Vetsch, D., Fäh, R., Farshi, D., and Müller, R.: BASEMENT An object-oriented software system for the simulation of natural hazards Festtagskolloquium 75 Jahre VAW, Oktober 2005, Mitteilung VAW 190, 201-212, 2005.

Vogt, T., Hoehn, E., Schneider, P., and Cirpka, O. A.: Investigation of bank filtration in gravel and sand aquifers using time-series analysis, Grundwasser, 14, 179-194, 2009.

Vogt, T., Hoehn, E., Schneider, P., Freund, A., Schirmer, M., and Cirpka, O. A.: Fluctuations of Electric Conductivity as Natural Tracer for Bank Filtration in a Losing Stream, Adv. Water Resour., 33, 1296-1308, 2010a.

Vogt, T., Schneider, P., Hahn-Woernle, L., and Cirpka, O. A.: Estimation of seepage rates in a losing stream by means of fiber-optic high-resolution temperature profiling, J. Hydrol., 380, 154-164, 2010b.

von Gunten, H. R., Karametaxas, G., and Keil, R.: Chemical processes in infiltrated riverbed sediments, Environ. Sci. Technol., 28, 2087-2093, 1994.

von Gunten, U. and Zobrist, J.: Biogeochemical changes in groundwater-infiltration systems:column studies, Geochim. Cosmochim. Acta, 57, 3895-3906, 1993.
Ward, J. V.: The 4-dimensional nature of lotic ecosystems, J. N. Am. Benthol. Soc., 8, 2-8, 1989.

Woessner, W. W.: Stream and fluvial plain ground water interactions: Rescaling hydrogeologic thought, Ground Water, 38, 423 429, 2000.

Wombacher, A. and Schneider, P.: Observation Centric Sensor Data Model. Technical Report TR-CTIT-10-13, Centre for Telematics and Information Technology University of Twente, Enschede, ISSN 1381-3625, 2010.

Woolsey, S., Capelli, F., Gonser, T., Hoehn, E., Hostmann, M., Junker, B., Paetzold, A., Roulier, C., Schweizer, S., Tiegs, S. D., Tockner, K., Weber, C., and Peter, A.: A strategy to assess river restoration success, Freshwater Biol., 52, 752-769, 2007.

Wroblicky, G. J., Campana, M. E., Valett, H. M., and Dahm, C. N.: Seasonal variation in surface-subsurface water exchange and lateral hyporheic area of two stream-aquifer systems, Water Resour. Res., 34, 317-328, 1998.

Zurbuchen, B. R., Zlotnik, V. A., and Butler, J. J.: Dynamic interpretation of slug tests in highly permeable aquifers, Water Resour. Res., 38, 1025, doi:10.1029/2001WR000354, 2002. 